\title{
$\gamma$-Polyglutamic acid/chitosan nanoparticles for the plant growth regulator gibberellic acid: Characterization and evaluation of biological activity
}

\author{
A.E.S. Pereira ${ }^{\mathrm{a}, \mathrm{d}}$, I.E. Sandoval-Herrera ${ }^{\mathrm{b}}$, S.A. Zavala-Betancourt ${ }^{\mathrm{b}}$, H.C. Oliveira ${ }^{\mathrm{c}}$, \\ A.S. Ledezma-Pérez ${ }^{b}$, J. Romero ${ }^{\mathrm{b}, * *}$, L.F. Fraceto $^{\mathrm{a}, \mathrm{d}, *}$ \\ a Department of Biochemistry, State University of Campinas (UNICAMP), Campus Universitário Zeferino Vaz, s/n, Cidade Universitária, CEP 13083-870, \\ Campinas, São Paulo, Brazil \\ ${ }^{\mathrm{b}}$ Department of Advanced Materials, Applied Chemistry Research Center (CIQA), Blvd. Enrique Reyna Hermosillo, 140, C.P. 25250, Saltillo, Coahuilla, Mexico \\ ${ }^{c}$ Department of Animal and Plant Biology, University of Londrina, PR 445 KM 380, CEP 86057-970, Londrina, PR, Brazil \\ d São Paulo State University (UNESP), Institute of Science and Technology, Sorocaba, Avenida Três de Março, 511, CEP 18087-180, Sorocaba, São Paulo, Brazil
}

\section{A R T I C L E I N F O}

\section{Article history:}

Received 9 August 2016

Received in revised form 27 October 2016

Accepted 19 November 2016

Available online 27 November 2016

\section{Keywords:}

$\gamma$-Polyglutamic acid

Chitosan

Nanoparticles

Gibberellic acid

Agriculture

Release system

\begin{abstract}
A B S T R A C T
The growth regulator gibberellic acid $\left(\mathrm{GA}_{3}\right)$ has several uses in the field, improving germination, plant development, productivity, and the quality of food. This work describes the development of a nanocarrier system for $\mathrm{GA}_{3}$, based on the poly $(\gamma$-glutamic acid) ( $\gamma$-PGA) and chitosan (CS) polymers, Nanoparticles without $\mathrm{GA}_{3}$ (nano- $\gamma \mathrm{PGA} / \mathrm{CS}-\mathrm{GA}_{3}$ ) showed colloidal characteristics, with an average size of $117 \pm 9 \mathrm{~nm}$, PDI of $0.43 \pm 0.07$, and zeta potential of $-29 \pm 0.5 \mathrm{mV}$. The encapsulated nanoparticles (nano- $\gamma \mathrm{PGA} / \mathrm{CS}-$ $\mathrm{GA}_{3}$ ) presented an average size of $134 \pm 9 \mathrm{~nm}$, PDI of $0.35 \pm 0.05$, zeta potential of $27.9 \pm 0.5 \mathrm{mV}$, and $61 \%$ encapsulation. The images of nanoparticles observed by Transmission and scanning electron microscopy (TEM and SEM) showed a spherical shape of the nanoparticles. The system showed sustained release, with 58\% release after $48 \mathrm{~h}$. Evaluation of thermal properties using DSC and TGA analyses indicated that there was an interaction between the CS and $\gamma$-PGA polymers. In tests using Phaseolus vulgaris seeds, nano- $\gamma \mathrm{PGA} / \mathrm{CS}-\mathrm{GA}_{3}$ showed high biological activity, enhancing the rate of germination in the first day (50-70\%) when compared with free $\mathrm{GA}_{3}(10-16 \%)$. Encapsulated $\mathrm{GA}_{3}$ was also more efficient than the free hormone in the increase of leaf area and the induction of root development (including the formation of lateral roots). These effects were not observed when seeds were treated with nano- $\gamma \mathrm{PGA} / \mathrm{CS}$ without $\mathrm{GA}_{3}$. The results demonstrated the considerable potential of nano- $\gamma \mathrm{PGA} / \mathrm{CS}-\mathrm{GA}_{3}$ for use in agriculture.
\end{abstract}

(C) 2016 Elsevier Ltd. All rights reserved.

\section{Introduction}

A number of recent studies have highlighted the potential of nanotechnology for applications in the agricultural sector that could help to improve food safety and quality, while increasing the sustainability of agricultural practices (Fraceto et al., 2016). Such uses include systems for the controlled release of fertilizers (DeRosa, Monreal, Schnitzer, Walsh, \& Sultan, 2010) and agents employed to protect plants against pests (Campos, de Oliveira, \&

\footnotetext{
* Corresponding author at: ICTS - UNESP, Avenida Três de Março, 511, Alto da Boa Vista, CEP 18087-180, Sorocaba, São Paulo, Brazil.

** Corresponding author at: Blvd. Enrique Reyna No. 140, Col. San José de los Cerritos, 25294, Saltillo, Coah, México.

E-mail addresses: Jorge.romero@ciqa.edu (J. Romero), leonardo@sorocaba.unesp.br (L.F. Fraceto).
}

Fraceto, 2014; Campos, de Oliveira, Fraceto, \& Singh, 2014; Grillo, Abhilash, \& Fraceto, 2016). Nanoparticles can act directly (He, Liu, Mustapha, \& Lin, 2011; Mishra et al., 2014) or as carrier systems for chemicals used in the field (Ihegwuagu et al., 2016), providing greater efficiency and improved environmental safety (Sekhon, 2014). For example, the use of nanocarriers for herbicides results in more effective weed control, together with reduced toxic effects towards nontarget organisms (de Oliveira et al., 2015; Oliveira et al., 2015; Maruyama et al., 2016). de Oliveira et al. (2015) demonstrated that solid lipid nanoparticles containing the herbicides simazine and atrazine caused phytotoxic effects in target plants, even after 10-fold dilution. Similar results have been observed for atrazine-containing polymeric nanocapsules (Oliveira et al., 2015). Maruyama et al. (2016) observed a reduction of around $100 \%$ in the genotoxicity of the herbicides imazapic and imazapyr after their encapsulation into chitosan nanoparticles. Nanocarriers have also 
been employed with other classes of pesticides, such as fungicides (Campos et al., 2015; Manikandan \& Sathiyabama, 2016) and insecticides (Elek et al., 2010), improving their biological effectiveness and stability. The chemical agent is protected against degradation caused by processes such as photolysis and hydrolysis, while at the same time its adverse effects in non-target organisms are reduced (Khot, Sankaran, Maja, Ehsani, \& Schuster, 2012; Nair et al., 2010).

Although these systems have been developed for different classes of agrochemicals, there have been few studies involving plant growth regulators. Plant growth regulators are a class of compounds used in agriculture to improve the development of plants or fruits, and include gibberellins, auxins, cytokinins, abscisic acid, nitric oxide, and ethylene, amongst others (Nambara, 2013). In 2014 , these compounds accounted for around $2.5 \%$ of the global market for agricultural inputs (Rademacher, 2015). Growth regulators, whether from synthetic or natural origins, are employed in various ways to increase productivity and profitability (E1-Otmani, Coggins Jr., Agustí, \& Lovatt, 2000). Microparticulate release systems have been used for brassinosteroid hormones (Quiñones, García, Curiel, \& Covas, 2010) and naphthalene acetic acid (Tao, Pang, Chen, Ren, \& Hu, 2012), and chitosan nanoparticles have been used for the controlled release of nitric oxide (Oliveira, Gomes, Pelegrino, \& Seabra, 2016). Studies have shown that carbon nanotubes induce effects similar to those of plant hormones; for example, Khodakovskaya et al. (2013) showed that the use of multi-walled carbon nanotubes could increase twice the flowers and fruits of tomato. Other types of nanoparticles can also alter physiological and biochemical processes in plants (McDaniel, Chen, Balogh, Yang, \& Ghoshroy, 2013; Servin et al., 2012).

The gibberellic acid $\left(\mathrm{GA}_{3}\right)$ plant hormone (Rodrigues, de Vandenberghe, de Oliveira, \& Soccol, 2012) is widely used to stimulate plant development, affecting seed germination, stem elongation, leaf area expansion, and maturation of plant sexual organs, as well as reducing the time to flowering, amongst other functions (Bose et al., 2013; Wani et al., 2014). The application of $\mathrm{GA}_{3}$ delayed ripening and improved the weight and quality of the fruit of the 'Barhee' date palm cultivar (Awad \& Al-Qurashi, 2012). In combination with phosphorous, this plant hormone was shown to alter the metabolism and increase the seed yield of Trigonella foenum-graecum plants (Dar et al., 2015). The use of $\mathrm{GA}_{3}$ can also help to break seed dormancy (Miransari \& Smith, 2014) and produce parthenocarpic fruits (Mesejo, Reig, \& Martínez-Fuentes, 2010). However, degradation of the compound in the field reduces its effectiveness, necessitating the use of suitable carrier systems able to increase its chemical stability as well as its biological effects (Liu et al., 2013a). A conjugated system with chitosan has been described for the controlled release of $\mathrm{GA}_{3}$ (Liu et al., 2013a). Hafez, Berber, Minagawa, Mori, and Tanaka (2010) developed a nanohybrid system for $\mathrm{GA}_{3}$ using an inorganic magnesium-aluminum layered double-hydroxide material, which resulted in sustained release and slow degradation of the hormone. Despite these studies, the development of biopolymer-based nanoparticles as carrier systems for $\mathrm{GA}_{3}$ has not yet been described.

Biopolymers such as alginate, cellulose, cyclodextrin, dextran, pectin, and chitosan, amongst others, can be employed as carrier systems for agrochemicals (Campos, de Oliveira, Fraceto et al., 2014; Campos, de Oliveira, Fraceto, Singh et al., 2014). The $\gamma$-PGA polymer is produced by fermentation using bacteria of the genus Bacillus (Ogunleye et al., 2015). This biopolymer is hydrophilic, biodegradable, non-toxic and edible, and has many potential applications in the food, pharmaceutical, cosmetics, and waste treatment industries, as well as in other areas (Bajaj \& Singhal, 2011; Chang, Zhong, Xu, Yao, \& Chen, 2013). The $\gamma$-PGA polymer is anionic due to the presence of carboxylic groups that can interact electrostatically with cationic polymers (Sung, Sonaje, Liao, Hsu, \& Chuang, 2012).
Chitosan (CS) is a polysaccharide derived from the deacetylation of chitin (Riteau \& Sher, 2016). It is biodegradable and nontoxic, and has various applications in the food, pharmaceutical, and cosmetics industries, as well as in other areas (Zargar, Asghari, \& Dashti, 2015).

No carrier systems using the $\gamma$-PGA polymer with CS have been reported for the delivery of agrochemicals. However, this system offers properties different to those of other systems in terms of the characteristics of the nanoparticles, release of the active agent, and interaction with target plants. The present work therefore describes the preparation and characterization of nanoparticles composed of $\gamma$-PGA and CS (nano- $\gamma$ PGA/CS), as a carrier system for the $\mathrm{GA}_{3}$ plant growth regulator (nano- $\gamma \mathrm{PGA} / \mathrm{CS}-\mathrm{GA}_{3}$ ). The profile and mechanism of its release were examined as well as the biological activity using Phaseolus vulgaris (bean) as a model that could be a new system suitable for application in agriculture.

\section{Materials and methods}

\subsection{Materials}

The $\gamma$-PGA polymer (290 kDa, polydispersity index 2.2 ) was produced by the Bacillus licheniformis strain at the Applied Chemistry Research Center (Saltillo, Coahuila, Mexico). The CS polymer (MW: $27 \mathrm{kDa}$; degree of deacetylation: 75-85\%) and cellulose membrane (dialysis tubing with molecular exclusion pore size of $12000 \mathrm{Da}$ ) were purchased from Sigma-Aldrich. Acetonitrile (HPLC grade) was from J.T. Baker. Phaseolus vulgaris seeds were purchased locally in the town of Saltillo (Coahuila, Mexico).

\subsection{Preparation of nano- $\gamma$ PGA/CS}

The nanoparticles were prepared according to the ionic pregelation method proposed by Sarmento et al. (2006), with modifications. Firstly, a $\mathrm{CaCl}_{2}$ solution $(25 \mathrm{mM})$ was added to $59 \mathrm{~mL}$ of a solution of $\gamma$-PGA $(0.031 \%, \mathrm{pH} 4.9)$ over a period of $60 \mathrm{~min}$, under stirring, using a peristaltic pump. A $12.5 \mathrm{~mL}$ volume of CS solution $(0.07 \%, \mathrm{pH} 4.5)$ was then added to the $\gamma-\mathrm{PGA} / \mathrm{CaCl}_{2}$ solution over a period of $90 \mathrm{~min}$, using a peristaltic pump. Nanoparticles were prepared with and without $\mathrm{GA}_{3}$, with the active agent being added after addition of the $\mathrm{CaCl}_{2}$ solution and before addition of the CS solution. The final concentration of $\mathrm{GA}_{3}$ in the nanoparticle suspensions was $50 \mu \mathrm{g} / \mathrm{mL}$.

\subsection{Characterization}

\subsubsection{Nanoparticle characterization}

Nanoparticle size and polydispersity index measurements were performed using a NanoFlex instrument (Microtec, CIQA, Saltillo, Mexico). The samples were analyzed in triplicate at $25^{\circ} \mathrm{C}$. The zeta potentials of the nanoparticles were measured with a Zeta-Check particle charge reader. The equipment was previously calibrated using an aluminum solution with zeta potential of $+50 \mathrm{mV}$. The samples were analyzed by triplicate at $25^{\circ} \mathrm{C}$. The $\mathrm{pH}$ analyses were performed with a Corning Model $450 \mathrm{pH} /$ ion meter that had been previously calibrated using $\mathrm{pH} 4$ and $\mathrm{pH} 7$ buffer solutions. The samples were analyzed by triplicate at $25^{\circ} \mathrm{C}$.

\subsubsection{Transmission and scanning electron microscopy (TEM and SEM)}

Samples containing the nanoparticles were dialyzed prior to the electron microscopy analyses. The solutions were placed into cellulose membrane dialysis tubing for $1 \mathrm{~h}$ and then were draw out to prepared several dillutions in water $(1: 4 \mathrm{v} / \mathrm{v})$, previously to the microscopy observation. Images were obtained using a JEOL Model JSM-7401F microscope at magnifications between $22,000 \times$ and $35,000 \times$. ImageJ v. 1.48 software was used to measure the size of 
the nanoparticles, with counting of 100 nanoparticles to construct the histograms and obtain the average size and polydispersity index values.

\subsection{Encapsulation efficiency}

The encapsulation efficiency values were determined indirectly by adding $400 \mu \mathrm{L}$ of the nanoparticle suspension to a Microcon regenerated cellulose ultrafiltration device (Millipore) with exclusion pore size of $30 \mathrm{kDa}$. The device was centrifuged at $200 \times \mathrm{g}$ for $30 \mathrm{~min}$ and the filtrate was analyzed by high performance liquid chromatography (Section 2.3.7). The encapsulation percentage was calculated from the quantified amount that was not encapsulated, considering a concentration of $50 \mu \mathrm{g} / \mathrm{mL}$ as $100 \%$.

\subsubsection{Quantification of $\mathrm{GA}_{3}$ by high performance liquid chromatography (HPLC)}

Quantification of gibberellic acid was performed using an Agilent Technologies Series 1200 instrument equipped with a quaternary pump, manual injector, refractive index detector, and temperature-controlled column compartment. The mobile phase (flow rate of $0.7 \mathrm{~mL} / \mathrm{min}$ ) was a solution of acetonitrile and water (containing $\left.0.1 \% \mathrm{H}_{3} \mathrm{PO}_{4}\right)$, in a ratio of $3: 1(\mathrm{v} / \mathrm{v})$, and a Supelcosil LC18-DB column $(3.3 \times 4.6 \mathrm{~cm} ; 3 \mu \mathrm{m})$ was used as the stationary phase. $\mathrm{GA}_{3}$ was detected at $210 \mathrm{~nm}$ with a G1365D (1260MWD VL) UV detector (Agilent Technologies). The equipment was previously calibrated using standard solutions of $\mathrm{GA}_{3}$ (purity $>95 \%$, Sigma-Aldrich) at different concentrations. The linear correlation coefficient ( $r$ ) of the calibration curve was 0.9993 and the limits of detection and quantification were 0.97 and $3.24 \mu \mathrm{g} / \mathrm{mL}$, respectively. ChemStation 2D HPLC software was used to record and analyze the chromatograms.

\subsection{In vitro release assays}

The release assays were carried out using a system with two compartments (donor and acceptor) separated by a cellulose dialysis tubing membrane (Sigma) with molecular exclusion pore size of $1200 \mathrm{Da}$. The assays were performed in triplicate for the carrier and the free $\mathrm{GA}_{3}$. The donor compartment was filled with $6 \mathrm{~mL}$ of solution containing $\mathrm{GA}_{3}$ and the acceptor compartment was filled with $25 \mathrm{~mL}$ of $\mathrm{CaCl}_{2}$ solution ( $18 \mathrm{mM}, \mathrm{pH} 4.3$ ). These proportions and volumes ensured that the assays were performed under sink conditions. After the start of each test, aliquots were periodically collected for quantification of $\mathrm{GA}_{3}$ by HPLC (Section 2.3.7).

\subsection{Differential scanning calorimetry (DSC)}

The DSC analyses were performed using a Discovery thermal analyzer (TA Instruments/Waters). The nanoparticle samples were centrifuged at $200 \times g$ and then lyophilized. Aliquots $(5 \mathrm{mg}$ ) were weighed into alumina crucibles and heated from 25 to $350^{\circ} \mathrm{C}$, at a rate of $10^{\circ} \mathrm{C} / \mathrm{min}$, under a flow of nitrogen $(50 \mathrm{~mL} / \mathrm{min})$.

\subsection{Thermogravimetric analysis (TGA)}

TGA analyses were performed using the Discovery thermal analyzer. The nanoparticle samples were centrifuged at $200 \times \mathrm{g}$ and then lyophilized. All the samples were heated from 25 to $600{ }^{\circ} \mathrm{C}$ under a flow of nitrogen, and from 600 to $800^{\circ} \mathrm{C}$ under a flow of oxygen (both at $50 \mathrm{~mL} / \mathrm{min}$ ), using a heating rate of $10^{\circ} \mathrm{C} / \mathrm{min}$.

\subsection{Bioactivity assays}

\subsubsection{Germination assays}

The Phaseolus vulgaris seeds were previously sterilized by placing in $10 \%$ hypochlorite solution for $10 \mathrm{~min}$, followed by immersion in sterilized distilled water for $5 \mathrm{~min}$, repeating this procedure three times. Subsequently, the seeds were treated by immersion for $1 \mathrm{~h}$ in solutions of nano- $\gamma \mathrm{PGA} / \mathrm{CS}-\mathrm{GA}_{3}$ or $\mathrm{GA}_{3}$ at concentrations equivalent to $2.1,0.7,0.23$, and $0.07 \mu \mathrm{g}$ of $\mathrm{GA}_{3}$ per gram of seeds. The same dilutions were used for nano- $\gamma \mathrm{PGA} / \mathrm{CS}$ without $\mathrm{GA}_{3}$, in order to evaluate the effects of the nanoparticles alone. The control used was deionized water, $\gamma$-PGA $(0.024 \%)$ and CS $(0.011 \%)$, diluted in the same concentrations found in the nanoparticles to evaluated the effect of the nanoparticles components.

Under a laminar flow hood, $20 \mathrm{~mL}$ of Hoagland solution containing $1.5 \%$ agar, autoclaved at $121^{\circ} \mathrm{C}$ for $15 \mathrm{~min}$ (Uamato SE 510 autoclave), was added to previously sterilized Petri plates, forming a solid base. The seeds were transferred to the plates then incubated in the dark using a chamber and kept at room temperature for 5 days. The assays were performed in triplicate $(n=10)$.

The effects of nano- $\gamma$ PGA/CS, nano- $\gamma$ PGA-GA 3 , and $\mathrm{GA}_{3}$ were assessed using the following variables: germination rate, root development (length of the primary root), and number of lateral roots. The percentage germination in the first two days of the experiment was calculated using:

$\%$ Germination $=N \times 100 / T S$

Where $N$ is the number of germinated seeds and TS is the total number of seeds used in the assay.

\subsubsection{Plant development}

To evaluate the effect of the nano- $\gamma$ PGA/CS-GA ${ }_{3}$ nanoparticles on the germination of $P$. vulgaris, seeds were treated as was described before (Section 2.8.1). The treated seeds were transferred to pots $(9.3 \mathrm{~cm}$ high, 12.5 and $9.3 \mathrm{~cm}$ upper and lower diameters, respectively) filled with $600 \mathrm{~g}$ of California substrate and kept in a greenhouse. At the end of 15 days shoot and root lengths, leaf area, and shoot and root dry masses were evaluated. The leaves were scanned and the area was calculated with ImageJ v. 1.48 software. The dry mass was determined by oven-drying the samples at $60^{\circ} \mathrm{C}$ for two days. The assays were performed in triplicate $(n=10)$.

\subsubsection{Statistical analysis}

The data were expressed as means and standard deviations, and were analyzed using one-way analysis of variance (ANOVA) followed by Tukey's test (at a significance level of 0.05). All the statistical procedures were performed using Graphpad Prism v. 5.01 software.

\section{Results and discussion}

\subsection{Nanoparticle size, polydispersity index, and $\mathrm{pH}$}

The nano- $\gamma \mathrm{PGA} / \mathrm{CS}$ particles presented an average size distribution of $117 \pm 9 \mathrm{~nm}$, PDI of $0.43 \pm 0.07$, and zeta potential of $-29 \pm 0.5 \mathrm{mV}$ (at $\mathrm{pH} 4.4 \pm 0.01$ ). In the case of nano- $\gamma \mathrm{PGA} / \mathrm{CS}-\mathrm{GA}_{3}$, the values were $134 \pm 9 \mathrm{~nm}$ (average size distribution), $0.35 \pm 0.05$ (PDI), and $-27.8 \pm 0.5 \mathrm{mV}$ (zeta potential, at $\mathrm{pH} 4.4 \pm 0.01$ ). The efficiency of encapsulation of $\mathrm{GA}_{3}$ in the particles was $61 \%$. The size and polydispersity index values obtained for the particles corroborated the results obtained in the TEM analyses (Fig. 1), where the particles were observed to be spherical in shape, with average sizes of $138 \pm 28 \mathrm{~nm}$ (nano- $\gamma$ PGA/CS) and $165 \pm 35 \mathrm{~nm}$ (nano- $\gamma \mathrm{PGA} / \mathrm{CS}-\mathrm{GA}_{3}$ ), and PDI values of 0.2 for both formulations. In the SEM analyses (Fig. 2), nano- $\gamma$ PGA/CS showed an average 
a)
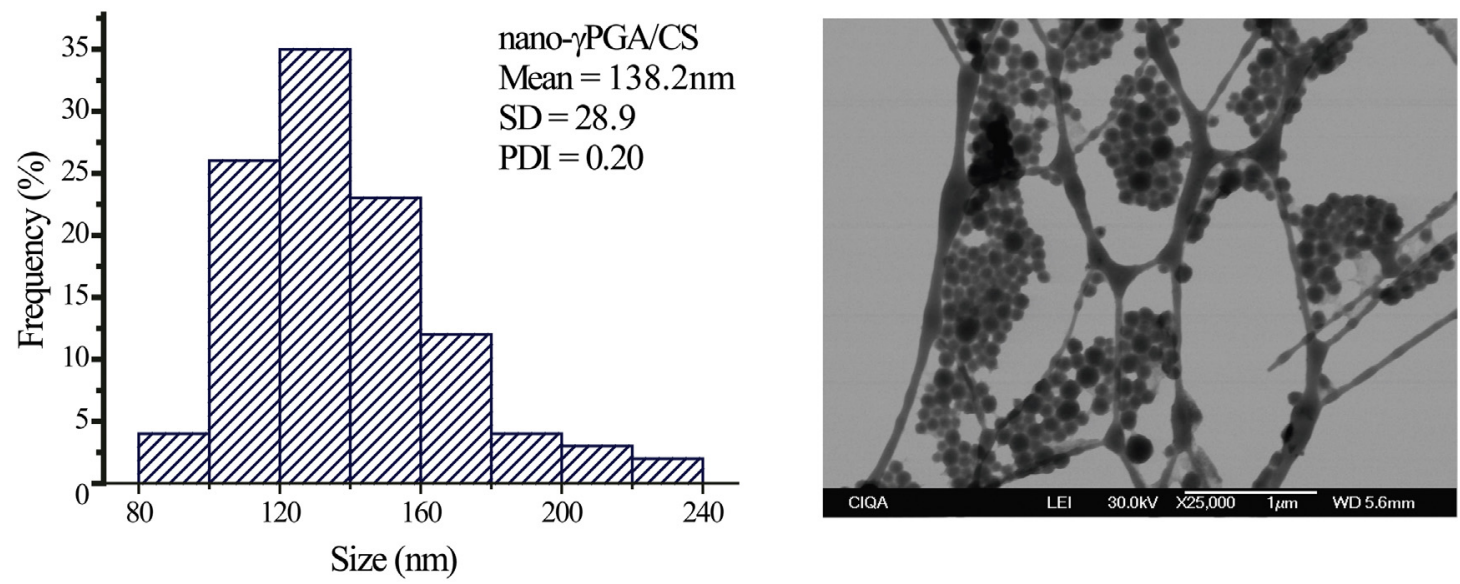

b)
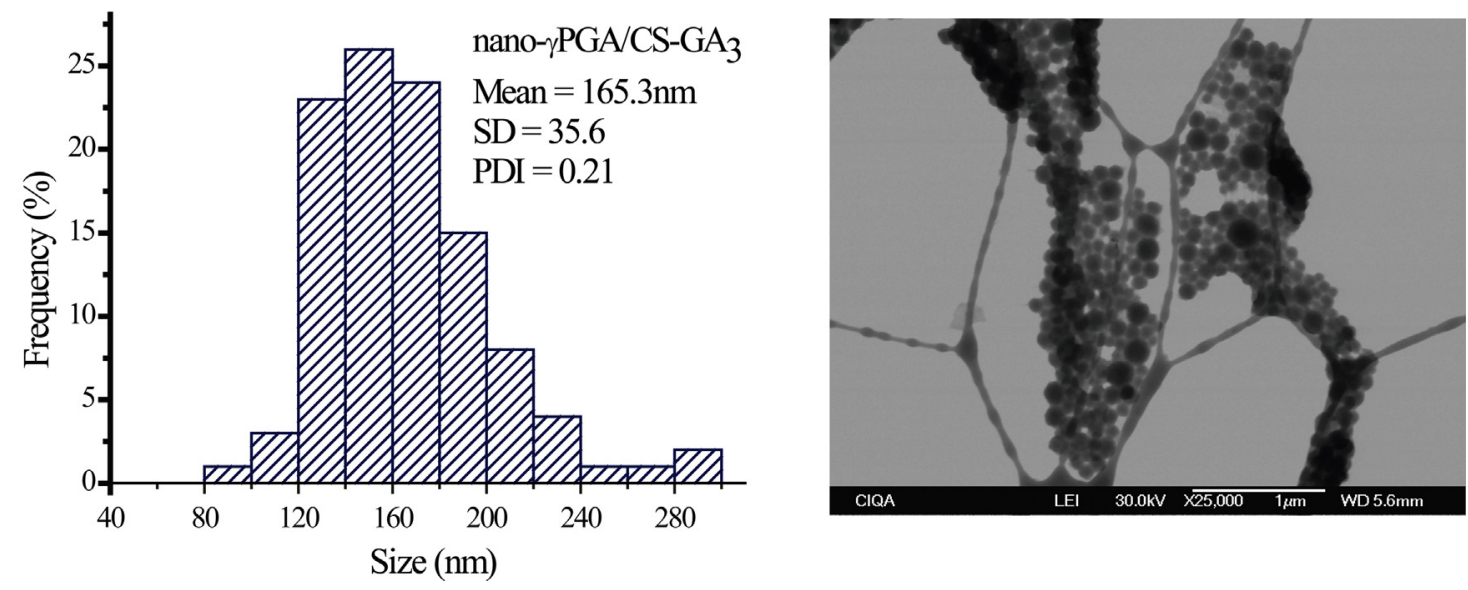

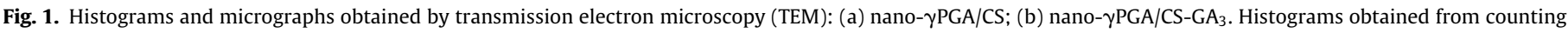
of 100 nanoparticles using ImageJ v. 1.48 software.

size of $120 \pm 26 \mathrm{~nm}$ and PDI of 0.2 , while the corresponding values for nano- $\gamma \mathrm{PGA} / \mathrm{CS}-\mathrm{GA}_{3}$ were $127 \pm 43 \mathrm{~nm}$ (average size) and 0.34 (PDI). It can be seen from Fig. 2 that the particles were spherical with wrinkled surfaces.

The techniques employed to characterize the nanoparticles demonstrated that the formulations presented homogeneous particle distributions. Hong, Lee, and Lee (2016) developed a carrier system for lutein, obtaining nanoparticles smaller than $400 \mathrm{~nm}$ (polydispersity in the range of $0.1-0.26$ ) by varying the concentrations of $\gamma$-PGA and CS, with higher concentrations of $\gamma$-PGA resulting in smaller particles. Liu et al. (2013b) obtained nanoparticles in the size range $240-610 \mathrm{~nm}$ for encapsulating lysozymes, by varying the concentrations of the two polymers.

Several factors among the microorganism strain, culture conditions and polymer purification, all these factors could provoke changes in molecular mass, polydispersity surface charge, hydrophobicity, and biocompatibility of $\gamma$-PGA polymer. The nature of the active agent to be encapsulated also affects the characteristics of the nanoparticles (Manocha \& Margaritis, 2008). The zeta potentials of the nanoparticles prepared in this study were negative and close to $-30 \mathrm{mV}$, indicative of good colloidal stability of the system due to increased repulsion between the nanoparticles, hence avoiding phenomena such as aggregation (Hans \& Lowman, 2002; Schaffazick, Guterres, de Lucca Freitas, \& Pohlmann, 2003). The zeta potential of these nanoparticles was negative due to the higher concentration of the $\gamma$-PGA polymer, which resulted in a greater presence of carboxylic groups on the surface (Liao et al., 2014). The nanoparticles obtained in the present work showed excellent colloidal characteristics, considering their size, polydispersity, and zeta potential, as well as good interaction with $\mathrm{GA}_{3}$.

\subsection{Release kinetics assays}

In vitro release assays were performed over a 5-day period. After $24 \mathrm{~h}$, there was $72 \%$ release of free $\mathrm{GA}_{3}$, compared to $53 \%$ release when the hormone was encapsulated. After $48 \mathrm{~h}$, release of free $\mathrm{GA}_{3}$ reached $98 \%$, while $58 \%$ of the encapsulated form was released in the same period (Fig. 3).

In agriculture practices, the use of system as the reported in this study could be beneficial to reduce the degradation of active agents due the processes involving microorganisms and hydrolysis and photolysis reactions, as well as decrease losses due to leaching and evaporation of the chemicals in the field (Campos, de Oliveira, Fraceto et al., 2014; Campos, de Oliveira, Fraceto, Singh et al., 2014). As a result, under encapsulated condition the active ingredient could be more available to plants, which can help to minimize the concentrations applied in the field (Nair et al., 2010).

In both cases, the concentration of the hormone decreased after $72 \mathrm{~h}$, due to the degradation of $\mathrm{GA}_{3}$. However, the slopes of the curves showed that the degradation rate was slower when the encapsulated $\mathrm{GA}_{3}$ was used, suggesting that encapsulation may protect the hormone from degradation. It has been reported pre- 
a)

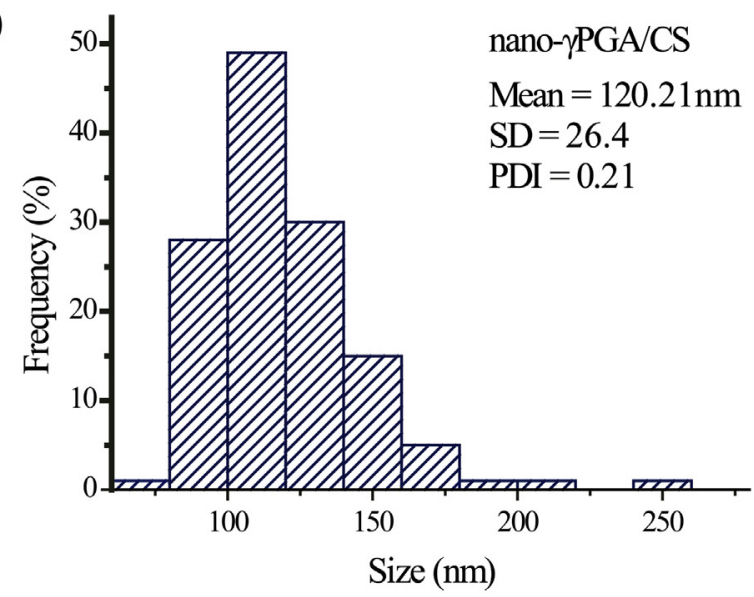

b)

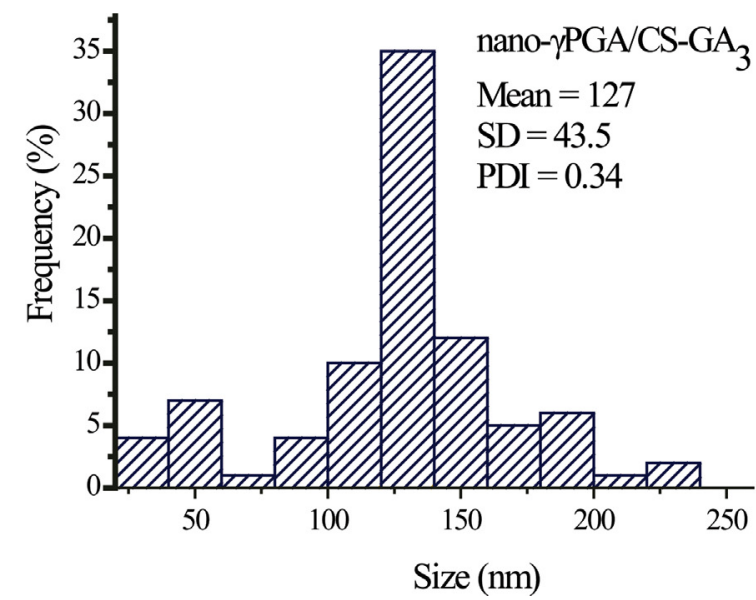

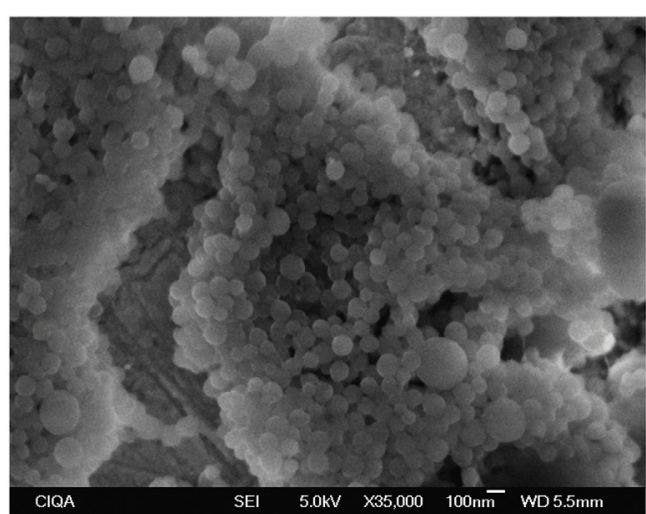

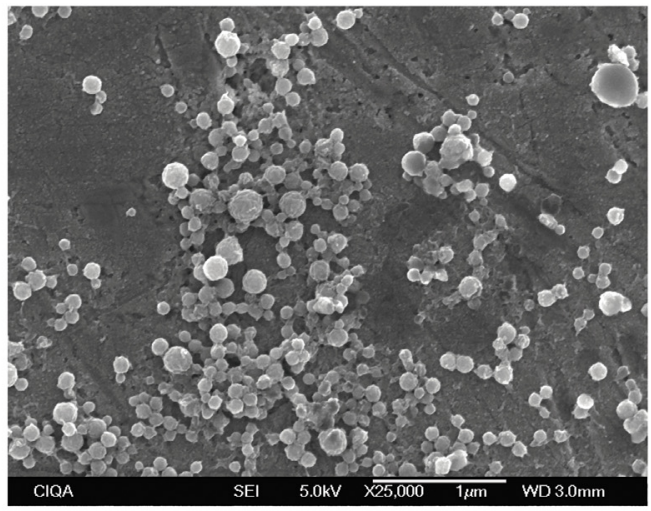

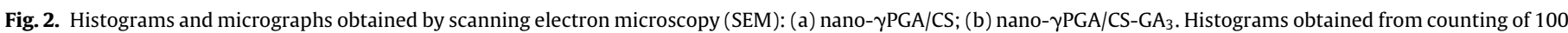
nanoparticles using ImageJ v. 1.48 software.

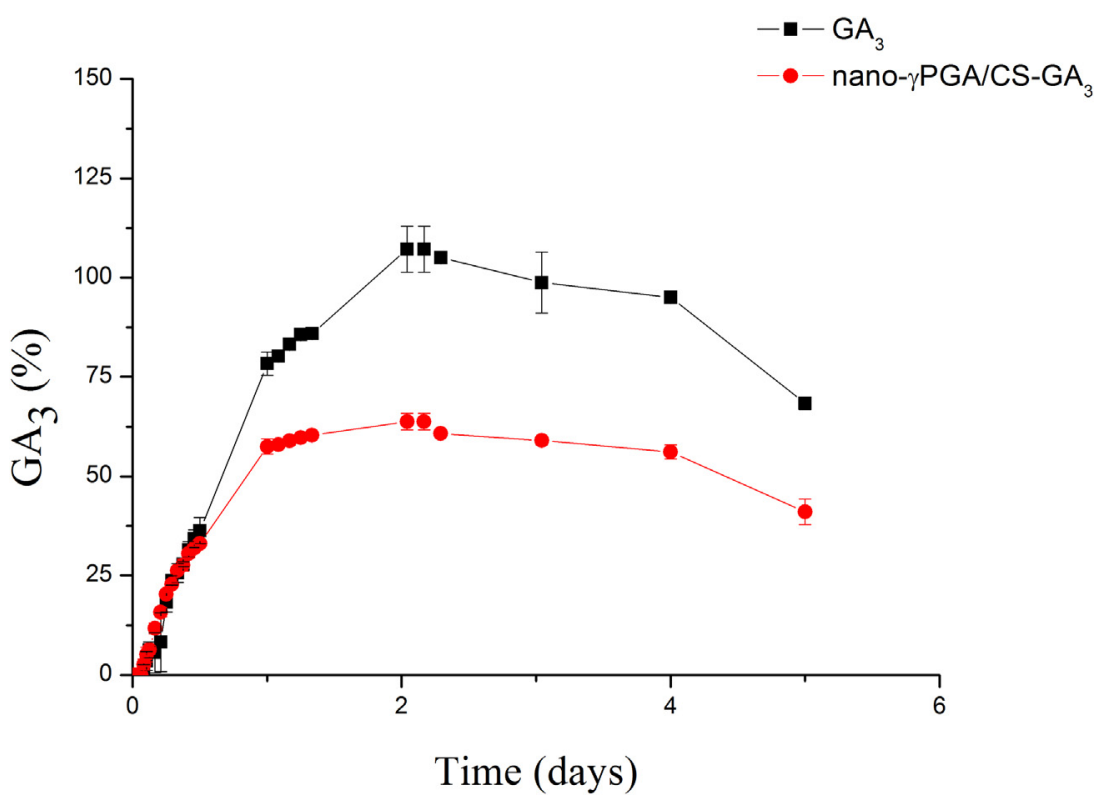

Fig. 3. Comparison of the results of release assays using nano- $\gamma \mathrm{PGA} / \mathrm{CS}-\mathrm{GA}_{3}$ and free $\mathrm{GA}_{3}$, during a period of 5 days $\left(\mathrm{n}=3\right.$ ). Tests performed at $25{ }^{\circ} \mathrm{C}$. 


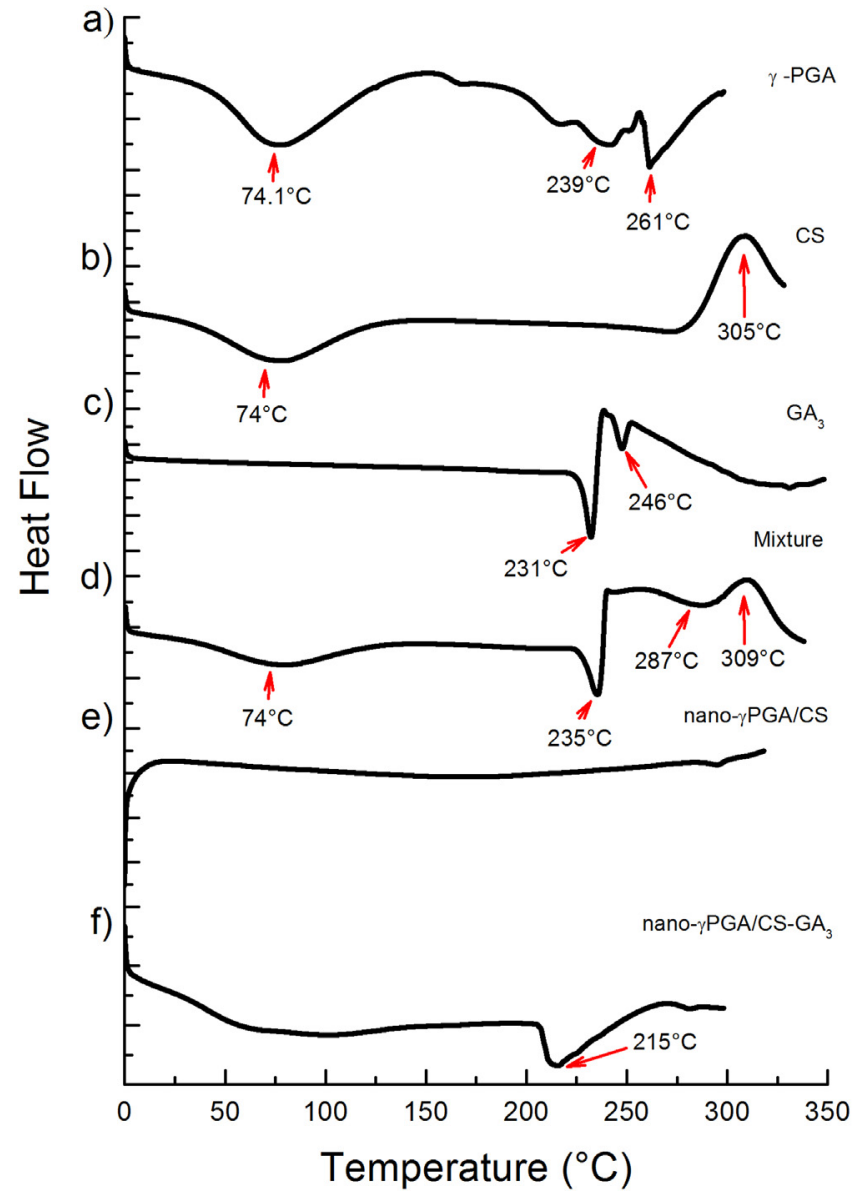

Fig. 4. DSC thermograms: (a) $\gamma$-PGA, (b) $C S$, (c) $\mathrm{GA}_{3}$, (d) physical mixture, (e) nano$\gamma \mathrm{PGA} / \mathrm{CS}$, and (f) nano- $\gamma \mathrm{PGA} / \mathrm{CS}-\mathrm{GA}_{3}$. Tests performed under a nitrogen atmosphere (flow rate of $50 \mathrm{~mL} / \mathrm{min}$ ), using a temperature interval of $25-350^{\circ} \mathrm{C}$ and a heating rate of $10^{\circ} \mathrm{C} / \mathrm{min}$.

viously that following application in the field, the stability and effectiveness of $\mathrm{GA}_{3}$ are negatively affected by factors including heat, light, and pH changes (Liu et al., 2013a). The use of carrier systems can mitigate such effects and improve the efficiency of hormone use.

\subsection{Differential scanning calorimetry (DSC)}

The DSC results are shown in Fig. 4, where it can be seen that the thermogram for the $\gamma$-PGA polymer (Fig. 4a) presented endothermic peaks at 74.1 and $240^{\circ} \mathrm{C}$.

In earlier work using low molecular weight $\gamma$-PGA, Garcia et al. (2013) reported a peak near $73^{\circ} \mathrm{C}$ as the phase transition point. Kubota et al. (1995) performed thermal analysis of $\gamma$-PGA with molecular mass between $10^{5}$ and $10^{6} \mathrm{Da}$, and observed a phase transition point at $220^{\circ} \mathrm{C}$. Elsewhere, no phase changes were detected between 45 and $300^{\circ} \mathrm{C}$ (Agresti, Tu, Ng, Yang, \& Liang, 2008). Manocha \& Margaritis (2008b) suggested that the $\gamma$-PGA polymer could exhibit different thermal characteristics, depending on the microorganism and the fermentation applied conditions, which can influence the molecular weight and consequently the physicochemical properties of the compound (such as viscosity).

The CS polymer (Fig. 4b) showed an endothermic peak at $74^{\circ} \mathrm{C}$ and an exothermic peak at $305^{\circ} \mathrm{C}$, corresponding to the fusion and degradation temperatures, respectively. These values are close to those found in the literature, with the endothermic peak being related to the loss of water associated with hydrophilic groups and the exothermic peak being due to degradation by depolarization and dehydration processes (Caddeo et al., 2016; Guinesi \& Cavalheiro, 2006; Sarmento, Ferreira, Veiga, \& Ribeiro, 2006). The thermogram for $\mathrm{GA}_{3}$ (Fig. 4c) showed an endothermic peak at $231^{\circ} \mathrm{C}$, corresponding to its fusion point (Palmer, 1974).

The thermogram for the physical mixture (Fig. 4d) presented peaks characteristic of the components $\gamma$-PGA, CS, and $\mathrm{GA}_{3}$, while nano- $\gamma \mathrm{PGA} / \mathrm{CS}$ showed no phase transition in the temperature range $25-350^{\circ} \mathrm{C}$ (Fig. 4e). Changes in the thermograms indicate interaction between the polymers (Emami, Boushehri, \& Varshosaz, 2014). In the case of the $\gamma$-PGA/CS-GA 3 nanoparticles (Fig. 4f), there was a shift in the hormone fusion peak from $235^{\circ} \mathrm{C}$ to $215^{\circ} \mathrm{C}$. The lower transition temperature could be related to different states of $\mathrm{GA}_{3}$ within the nanoparticles (Gref et al., 1994; Jeong et al., 2005). According to the fusion temperatures, there were no interactions of the active agent with the polymers used to produce the nanoparticles (Emami et al., 2014).

\subsection{Thermogravimetric analysis (TGA)}

The thermogravimetric analyses (Fig. 5) revealed that in the first step $\left(40-240^{\circ} \mathrm{C}\right)$, there was the loss of water from the samples.

The derivative thermogravimetry results indicated that degradation of the polymers occurred at temperatures of $253^{\circ} \mathrm{C}(\gamma$-PGA), $294^{\circ} \mathrm{C}(\mathrm{CS})$, and $262^{\circ} \mathrm{C}\left(\mathrm{GA}_{3}\right)$ (Han, Zhou, Yin, Yang, \& Nie, 2010). These degradation temperatures were close to those observed in the DSC analyses. The $\gamma$-PGA polymer (Fig. 5a) showed an initial mass loss of $6.5 \%$ related to the elimination of water, since this polymer is highly hydrophilic due to its polyacid nature. The depolymerization starts at around $200^{\circ} \mathrm{C}$, according to an unzipping mechanism, generating pyroglutamic acid and methyl pyroglutamate, followed by cyclodepolymerization of the polymer chain, with decomposition of the ionic complex by water absorption (Portilla-Arias, García-Alvarez, Martínez de Ilarduya, \& Muñoz-Guerra, 2007). In the case of CS (Fig. 5b), there was an initial mass loss of $6.3 \%$, due to the elimination of internal water of the polymer, followed by a second phase associated with the combustion of volatile components and subsequent pyrolysis reactions occurring randomly in the glycosidic linkages (Georgieva, Zvezdova, \& Vlaev, 2012). The physical mixture (Fig. 5d) showed two peaks at temperatures close to those found for the polymers (at 241 and $295^{\circ} \mathrm{C}$ ), with suppression of the peak for $\mathrm{GA}_{3}$ because its value was intermediate between the values for the polymer peaks. The thermogravimetry results showed values of $230^{\circ} \mathrm{C}$ for both types of nanoparticle (Fig. 5e and 5f). These were lower, compared to those of the neat polymers, reflecting decreases in the thermal stabilities. This alteration of thermal stability, together with the absence of peaks related to $\gamma$-PGA and CS in the thermograms of the nanoparticles, was indicative of interaction between the polymers (Tewary \& Zhang, 2015). In thermal studies of chitosan nanoparticles loaded with $\mathrm{GA}_{3}$, Liu et al. (2013a) found that the introduction of substituent groups in the polymer resulted in reduced crystallinity of CS and consequently lower stability of the nanoparticles, compared to pure CS. Abruzzo et al. (2013) reported that interaction between alginate and CS polymers reduced the maximum degradation temperature, due to a loss of structural organization following the formation of ionic bonds. The structural conformations of the $\gamma$-PGA and CS polymers are determined by hydrogen bridges (Lu et al., 2011; Martins, Pereira, Fajardo, Rubira, \& Muniz, 2011), and the breaking of these bridges during the formation of the nanoparticles generates new ionic bonds that decrease the thermal stability. 

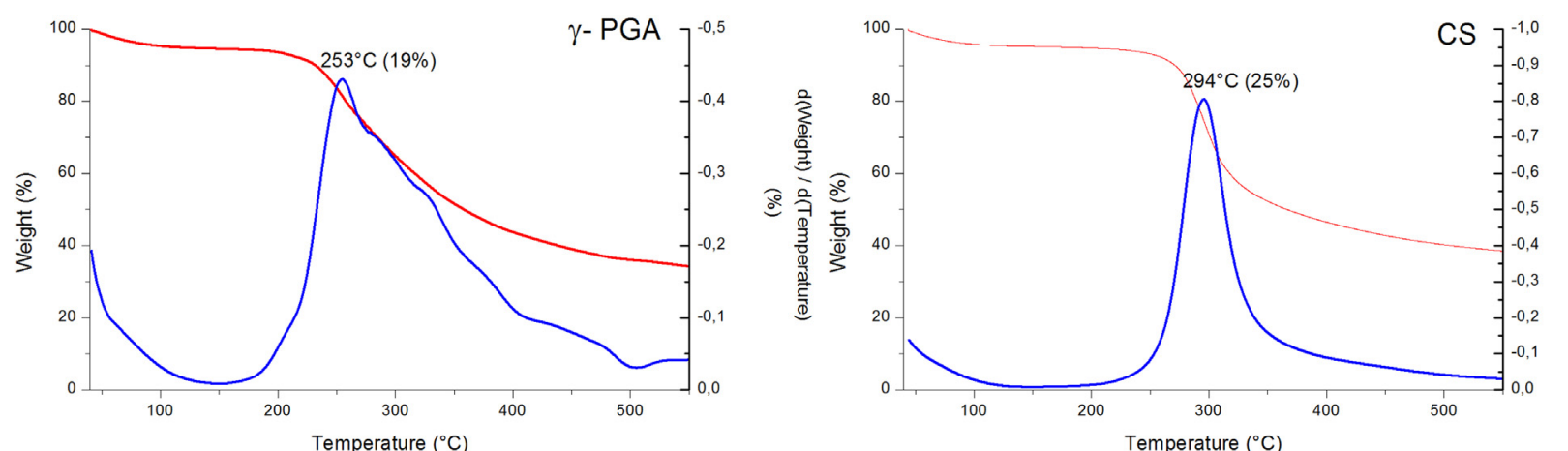

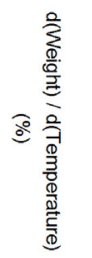
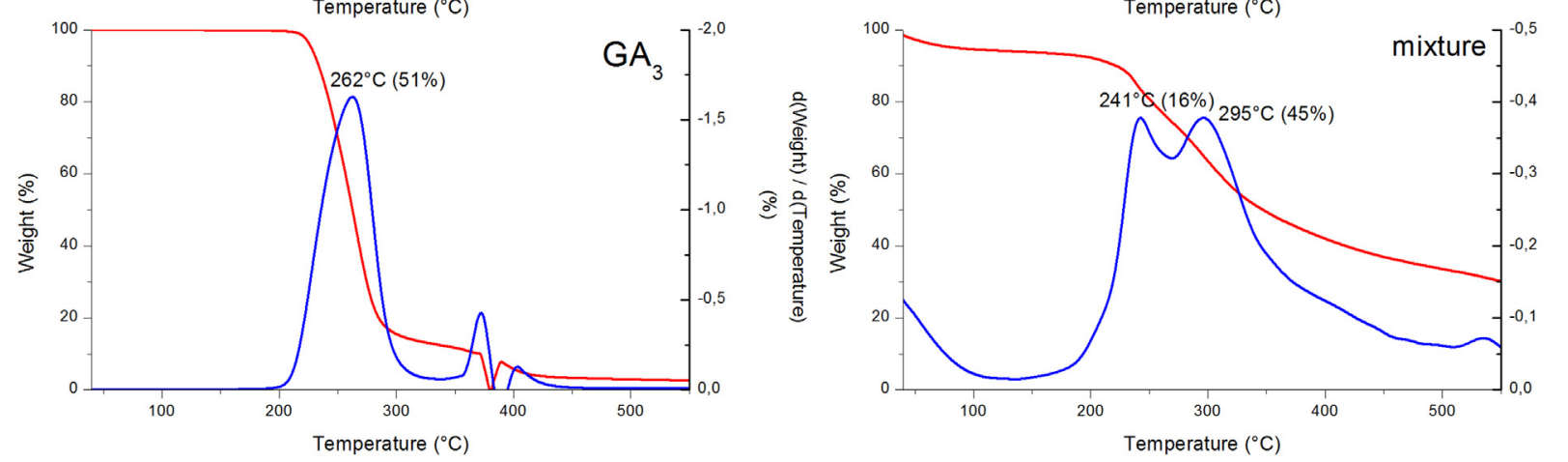

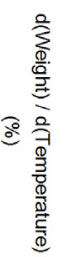
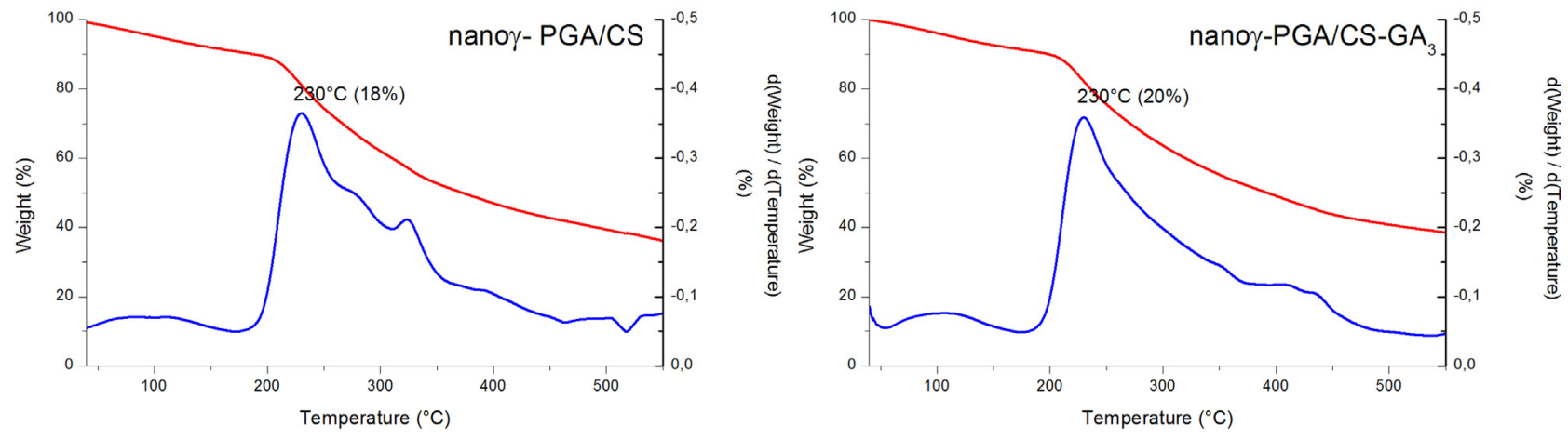

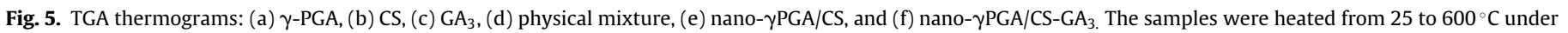
a flow of nitrogen $(50 \mathrm{~mL} / \mathrm{min})$, and from 600 to $800^{\circ} \mathrm{C}$ under a flow of oxygen $(50 \mathrm{~mL} / \mathrm{min})$. The heating rate was $10^{\circ} \mathrm{C} / \mathrm{min}$.

\subsection{Bioactivity assays}

\subsubsection{Germination index and root development}

Fig. 6 illustrates the development of the roots after germination of the seeds treated with different $\mathrm{GA}_{3}$ concentrations.

For $\mathrm{GA}_{3}$ concentrations of $2.1,0.7,0.23$, and $0.07 \mu \mathrm{g} / \mathrm{g}$ of seeds, the treatments with nano- $\gamma \mathrm{PGA} / \mathrm{CS}-\mathrm{GA}_{3}$ resulted in germination rates of $50,70,65$, and $23 \%$ on the first day, while the corresponding values for $\mathrm{GA}_{3}$ were $13,0,16$, and $0 \%$, respectively (Fig. 7a). These results indicated that encapsulation of the hormone in the nanoparticles favored the germination of Phaseolus vulgaris. However, it should be noted that the effect on germination was lower at the highest $\mathrm{GA}_{3}$ concentration. After $48 \mathrm{~h}$ (Fig. $7 \mathrm{~b}$ ), the encapsulated $\mathrm{GA}_{3}$ formulation continued to exert a greater effect on Phaseolus vulgaris, compared to the other solutions tested. This was due to the presence of $\mathrm{GA}_{3}$ in the nanoparticles, since the nano- $\gamma \mathrm{PGA} / \mathrm{CS}$ system (without $\mathrm{GA}_{3}$ ) showed no effect on germination.

It has been observed that the use of $\mathrm{GA}_{3}$ in plants can improve germination but may inhibit development of the plant, depending on the concentration applied (Leite, Rosolem, \& Rodrigues, 2003). Nanoparticle characteristics including size, polydispersity index, and zeta potential can determine the interactions of these nanomaterials with plants, hence influencing the physiological responses (Abraham et al., 2013; Schwab et al., 2015).
The use of nanoparticles can provide better targeting of active agents towards the undesired organisms, increasing their effectiveness (Nair et al., 2010). GA 3 is used in seed treatments in order to induce germination, acting on three processes: $i)$ water uptake (where $\mathrm{GA}_{3}$ acts as a negative regulator of repressor proteins in seed germination); ii) activation of metabolic processes; and iii) radicle emergence (Rajjou et al., 2012).

Use of the nano- $\gamma \mathrm{PGA} / \mathrm{CS}-\mathrm{GA}_{3}$ formulation at a $\mathrm{GA}_{3}$ concentration of $0.7 \mu \mathrm{g} / \mathrm{g}$ of seeds resulted in larger primary roots, compared to the control (Fig. 7c). The control showed roots with average length of $4.12 \pm 0.4 \mathrm{~cm}$, while the use of free $\mathrm{GA}_{3}$ and nano$\gamma \mathrm{PGA} / \mathrm{CS}-\mathrm{GA}_{3}$, at concentrations of $0.7 \mu \mathrm{g} / \mathrm{g}$ of seeds, resulted in average root lengths of $2.79 \pm 0.6 \mathrm{~cm}$ and $5.57 \pm 0.52 \mathrm{~cm}$, respectively. These results demonstrate that, at this concentration, the use of the nano- $\gamma \mathrm{PGA} / \mathrm{CS}-\mathrm{GA}_{3}$ formulation resulted in better development than both the control and the seeds treated with free $\mathrm{GA}_{3}$. As pointed out previously, $\mathrm{GA}_{3}$ improves germination in plants, but may inhibit the development of the plant, depending on the concentration applied (Leite et al., 2003). The application rate varies according to the plant, and prior studies are often required in order to adjust the applied concentration and obtain the best results in the field (Pavlista, Santra, Schild, \& Hergert, 2012). The use of nano$\gamma \mathrm{PGA} / \mathrm{CS}-\mathrm{GA}_{3}$ in different dosages led to good germination rates and root development. Analogous effects have been observed for 
a)
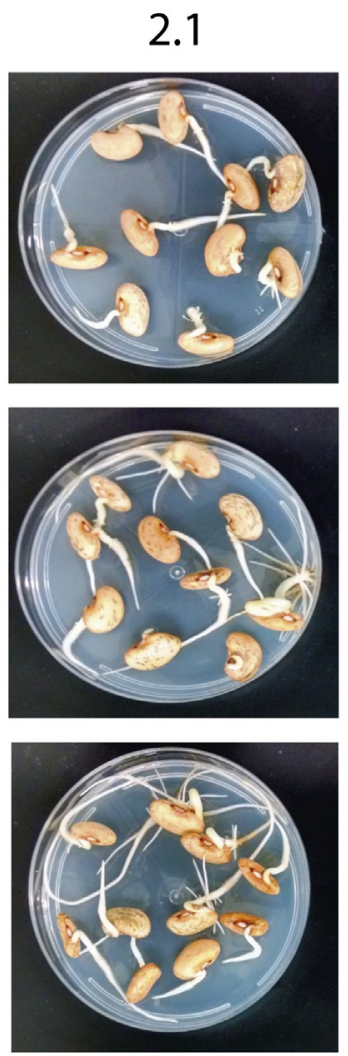

b)

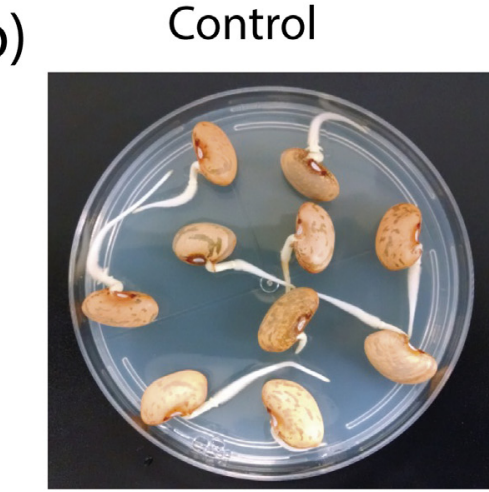

$\mu \mathrm{g}$ of $\mathrm{GA}_{3} / \mathrm{g}$ of seeds
0.7
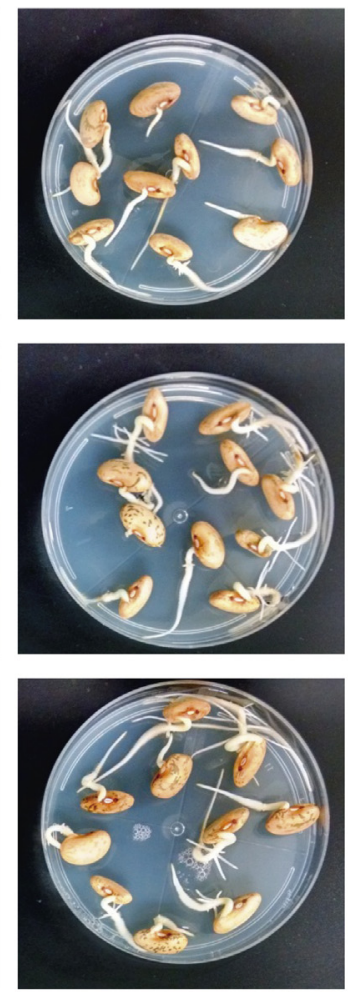

$\mathrm{GA} 3$

(0.7 $\mu \mathrm{g}$ of $\mathrm{GA} 3 / \mathrm{g}$ of seeds)

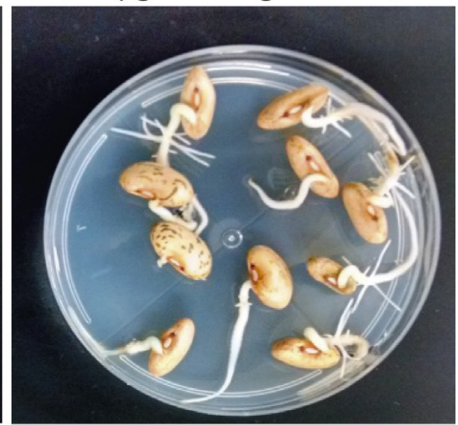

0.23
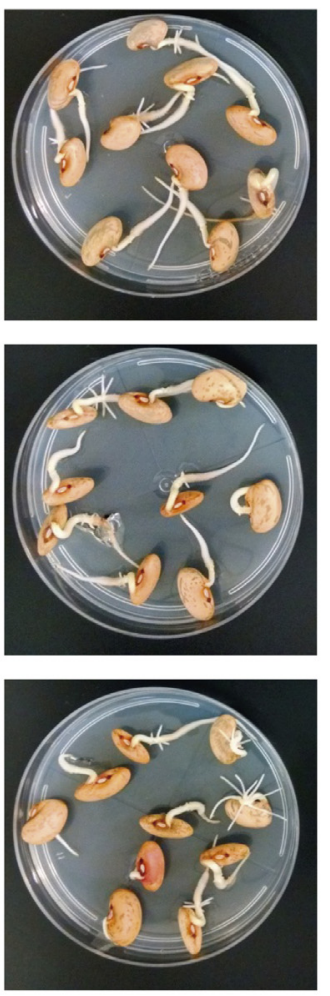

nano- $\gamma$ PGA/CS-GA3

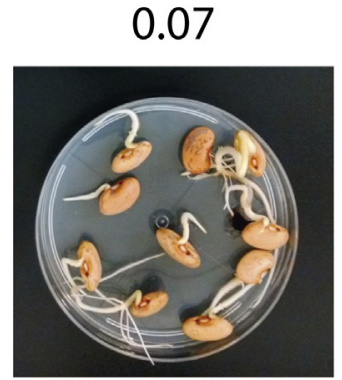

\begin{tabular}{l}
$\cup$ \\
$\frac{1}{0}$ \\
0 \\
$\frac{1}{7}$ \\
0 \\
$\frac{1}{0}$ \\
\multicolumn{1}{c}{}
\end{tabular}

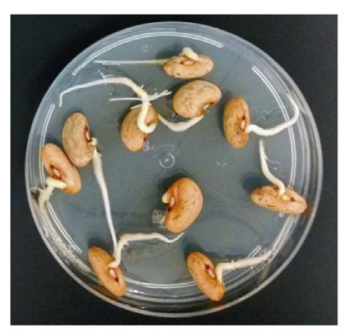

过

$\underbrace{m}_{1}$
$\vdots$
$\frac{1}{4}$
$\frac{1}{7}$
$\frac{1}{0}$
$\frac{1}{c}$
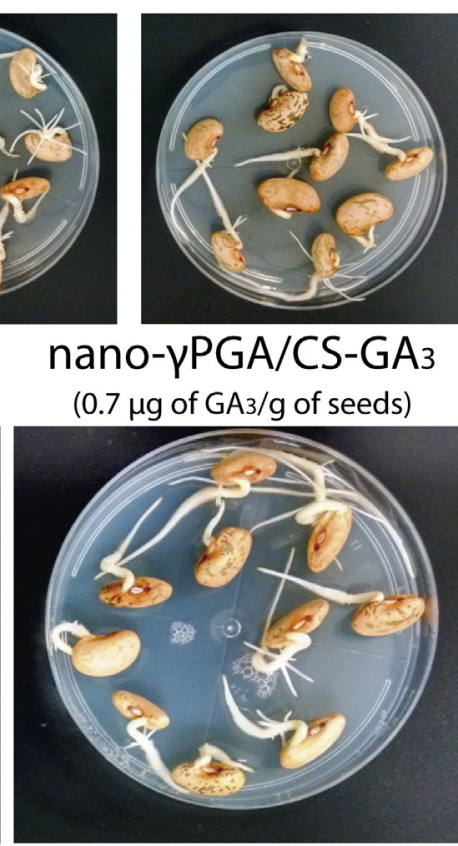

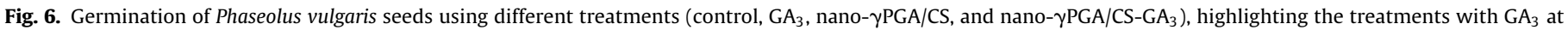
$0.7 \mu \mathrm{g} / \mathrm{g}$ of seeds, which produced the best results. The assays were performed in triplicate $(\mathrm{n}=10)$ in a chamber at $25^{\circ} \mathrm{C}$ in the dark.

drug delivery systems, where the use of these systems can reduce side effects of such as toxicity (De Jong \& Borm, 2008). This is due to the improved targeting achieved with the encapsulated active agent, together with the maintenance of optimal concentration levels due to sustained release, so that the biological effect is more pronounced.

Considering lateral root formation (Fig. 7d), treatment with CS reduced the number of roots, relative to the control. In agriculture, CS has been used for disease control, due to its fungicidal activity, as well to improve plant defense mechanisms, germination, product quality, and productivity (Kurita, 2006; Zeng et al., 2012). CS can also be used for biofilm formation and the creation of barriers (Badawy \& Rabea, 2011). As the seeds were treated using CS solutions, film formation and consequently reduced water uptake and gas exchange could have retarded the development of the plant. The control showed an average of $2.6 \pm 0.5$ lateral roots, with no statistically significant difference compared to the use of free $\mathrm{GA}_{3}$.
Use of the nano- $\gamma \mathrm{PGA} / \mathrm{CS}-\mathrm{GA}_{3}$ formulation at concentrations of 2.1, 0.7 , and $0.23 \mu \mathrm{g} / \mathrm{g}$ of seeds resulted in average numbers of lateral roots in the range 4.2-5.2.

At a concentration of $0.7 \mu \mathrm{g} / \mathrm{g}$, use of nano- $\gamma \mathrm{PGA} / \mathrm{CS}-\mathrm{GA}_{3}$ resulted in $5.4 \pm 0.9$ lateral roots, compared to $3.1 \pm 0.9$ for $\mathrm{GA}_{3}$, representing a gain of $74.1 \%$. As observed for germination, the properties of the nano- $\gamma \mathrm{PGA} / \mathrm{CS}-\mathrm{GA}_{3}$ formulation resulted in increased biological effectiveness of the plant hormone, with effects from germination to the early development of the roots.

In agriculture, greater formation of lateral roots is desirable because it increases the uptake of water and nutrients from the soil, which can help to reduce fertilizer use in the field (Lynch \& Brown, 2012). The literature describes different techniques using the $\gamma$-PGA polymer to prepare nanoparticles as carrier systems for biomedical applications, taking advantage of the rapid uptake of the nanoparticles by animal cells (Manocha \& Margaritis, 2008; Peng et al., 2009, 2011; Uto et al., 2007). According to Liao et al. (2014), 


\section{$2.1 \mu \mathrm{g} / \mathrm{g}$ of seed \\ $0.7 \mu \mathrm{g} / \mathrm{g}$ of seeds \\ $0.23 \mu \mathrm{g} / \mathrm{g}$ of seeds \\ $0.07 \mu \mathrm{g} / \mathrm{g}$ of seeds}
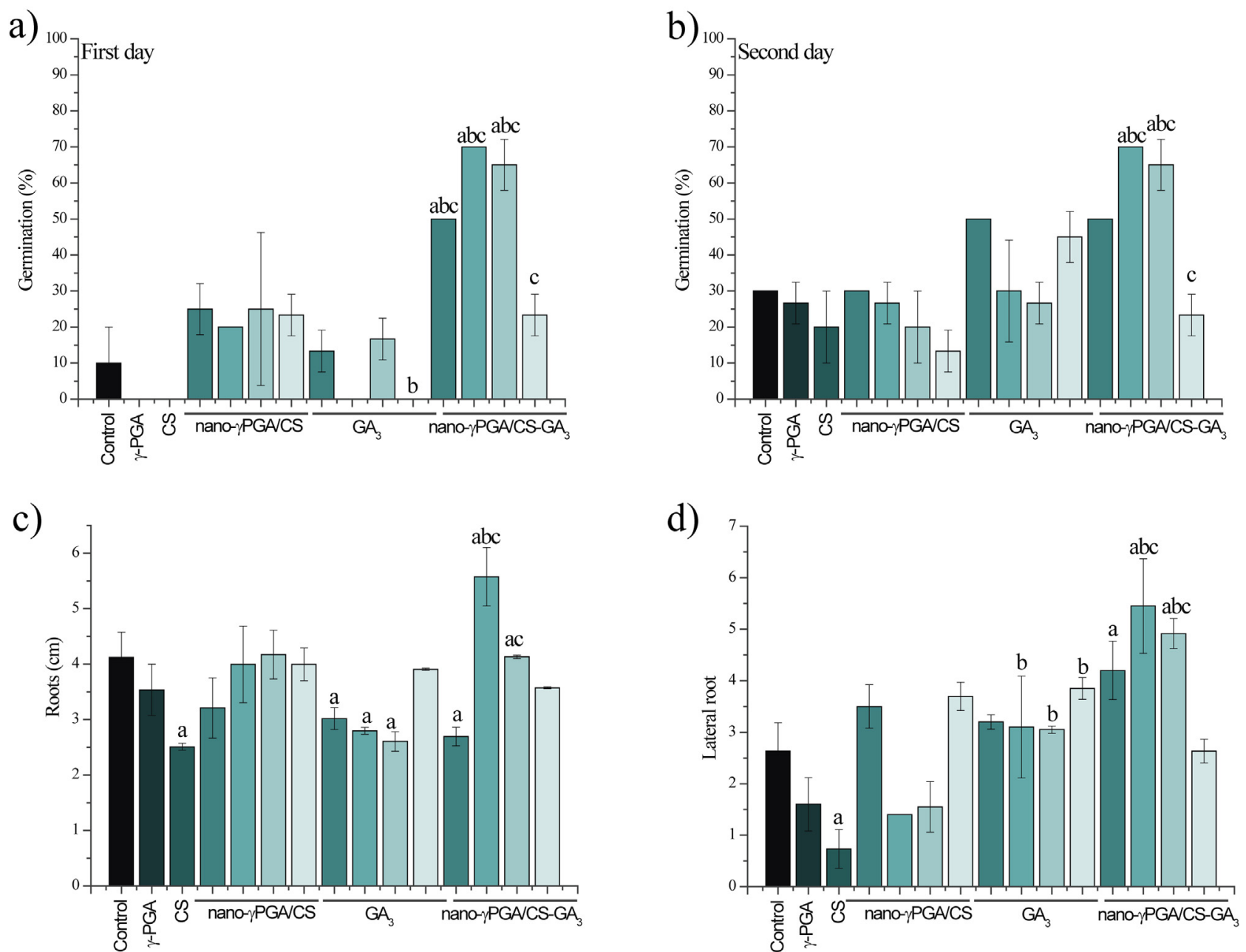

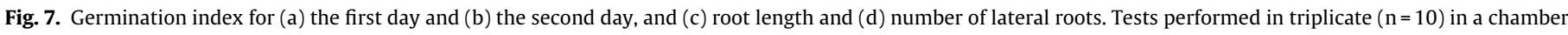

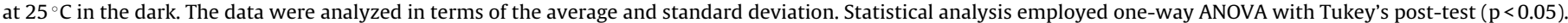
(a): significant difference relative to the control; (b): significant difference relative to nano- $\gamma \mathrm{PGA} / \mathrm{CS}$; (c): significant difference relative to free GA . $_{3}$

$\gamma$-PGA nanoparticles can easily enter cells, due to the presence of specific receptors in the cell membrane that mediate its entry. This advantage differentiates these nanoparticles from other systems. However, in the case of agricultural applications, further studies are required to determine whether the particles can exert the same effects in plant cells.

\subsubsection{Plant development}

The long-term effects on plant development of seed treatment with the formulations were evaluated 15 days after sowing (Fig. 8).

The treatments with $\mathrm{GA}_{3}$ or nano- $\gamma \mathrm{PGA} / \mathrm{CS}-\mathrm{GA}_{3}$ at 2.1 and $0.7 \mu \mathrm{g} / \mathrm{g}$ of seeds caused increases of $15-45 \%$ in shoot length, compared to the control (Fig. 8a). However, only encapsulated $\mathrm{GA}_{3}$ led to an increased shoot length at a dosage of $0.21 \mu \mathrm{g} / \mathrm{g}$ of seeds, with a value of $18.0 \pm 0.68 \mathrm{~cm}$, compared to a length of $14.9 \pm 0.43 \mathrm{~cm}$ for the control. Root length was not affected by any treatment (Fig. 8a). Nano- $\gamma \mathrm{PGA} / \mathrm{CS}-\mathrm{GA}_{3}$ at 0.7 and $0.23 \mu \mathrm{g} / \mathrm{g}$ of seeds enhanced the leaf area of the plants by 39 and $47 \%$, respectively, whereas none of the tested concentrations of free $\mathrm{GA}_{3}$ affected leaf area, compared to the control (Fig. 8b).

Shoot dry mass did not significantly differ between the control and the treatments. Differently, for root dry mass, the treatment with nano- $\gamma \mathrm{PGA} / \mathrm{CS}-\mathrm{GA}_{3}$ led to higher values than the control for all the concentrations tested (increases of $29,21,25$, and $41 \%$ for concentrations of $2.1,0.7,0.23$, and $0.07 \mu \mathrm{g} / \mathrm{g}$ of seeds, respectively). At 0.23 and $0.07 \mu \mathrm{g} / \mathrm{g}$ of seeds, nano- $\gamma \mathrm{PGA} / \mathrm{CS}-\mathrm{GA}_{3}$ was more effective than free $\mathrm{GA}_{3}$ in enhancing root dry mass. The observed effects on root dry mass were not caused by greater length of the primary root, but were probably due to increased formation of lateral roots, as observed in the germination assay.

The analysis of plant development under greenhouse conditions demonstrated that nano- $\gamma$ PGA/CS-GA ${ }_{3}$ was more efficient than free $\mathrm{GA}_{3}$ in stimulating plant growth, similar to the effects observed in the germination assay. The encapsulated $\mathrm{GA}_{3}$ was able to modulate plant development for longer periods, even 15 days after treatment of the seeds with the formulations.

These growth-promoting effects were related to $\mathrm{GA}_{3}$, rather than any other nanoparticle constituent, since the treatments with $\gamma$ PGA, CS, and nano- $\gamma$ PGA/CS did not affect any of the growth parameters of the $P$. vulgaris plants (Fig. 8). Therefore, the greater efficacy of nano- $\gamma \mathrm{PGA} / \mathrm{CS}-\mathrm{GA}_{3}$ could be explained by the controlled release of $\mathrm{GA}_{3}$ from the nanoparticles, as well as slower degradation of the encapsulated hormone, compared to free $\mathrm{GA}_{3}$ (Fig. 3). Other studies have reported the effective use of nanocar- 


\section{$2.1 \mu \mathrm{g} / \mathrm{g}$ of seeds $\quad 0.7 \mu \mathrm{g} / \mathrm{g}$ of seeds}

\section{$0.23 \mu \mathrm{g} / \mathrm{g}$ of seeds}

a)

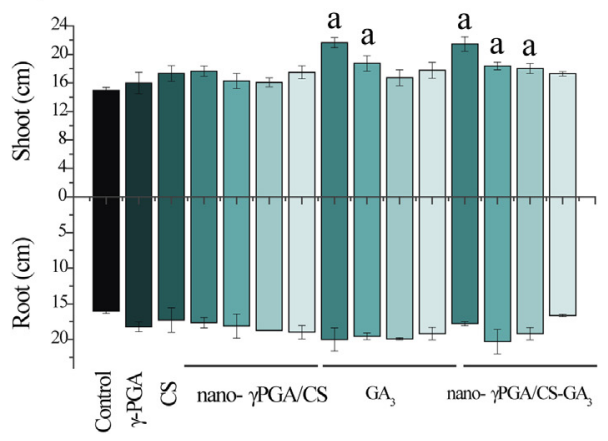

b)

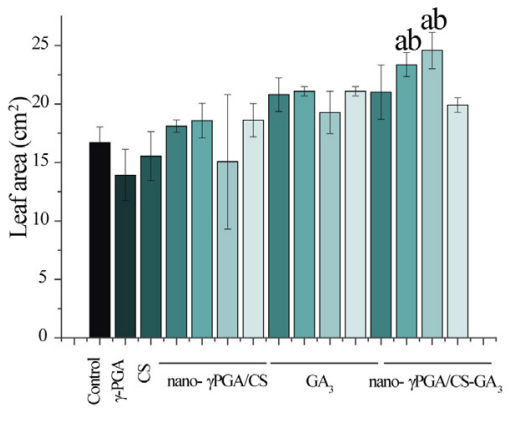

\section{$0.07 \mu \mathrm{g} / \mathrm{g}$ of seeds}

c)

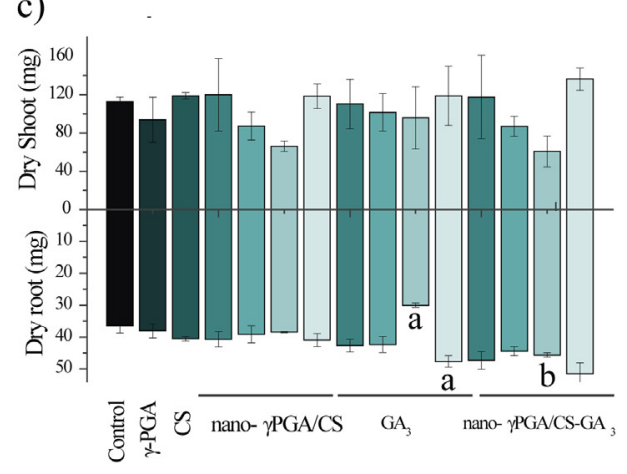

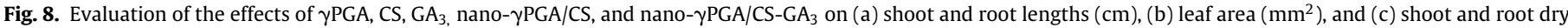

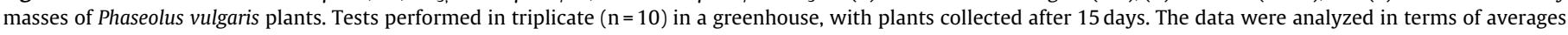

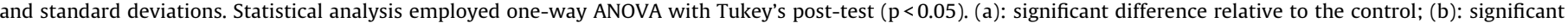
difference relative to nano- $\gamma \mathrm{PGA} / \mathrm{CS}$; (c): significant difference relative to free $\mathrm{GA}_{3}$.

riers for increasing the bioactivity of different agrichemicals. For example, atrazine-containing polymeric nanocapsules showed a 10-fold higher post-emergence herbicidal activity towards mustard plants, compared to free atrazine (Oliveira et al., 2015). In a recent study, Oliveira, Gomes, Pelegrino, \& Seabra (2016) demonstrated that nitric oxide-releasing CS nanoparticles were more effective than the free nitric oxide donor in protecting maize plants under salt stress. This enhanced bioactivity of nitric oxide was also related to the sustained release of the plant growth regulator by the nanoparticles (Oliveira, Gomes, Pelegrino, \& Seabra, 2016). The use of nanocarriers for plant growth regulators can therefore enable the use of lower dosages of these molecules, reducing both costs and the risk of phytotoxicity.

\section{Conclusions}

A high performance carrier system based on $\gamma$-PGA and CS polymers is described for use with the $\mathrm{GA}_{3}$ plant hormone. The nanoparticles presented ideal characteristics in terms of size, polydispersity, zeta potential, and encapsulation efficiency. In addition, the system provided sustained release, prolonging the release of the active agent as well as protecting it against degradation processes. In biological activity assays, the system was shown to be more effective, compared to the free hormone, accelerating germination within $24 \mathrm{~h}$ after treatment and increasing leaf area and root development (including the formation of lateral roots). This is the first study concerning the use of nano- $\gamma \mathrm{PGA} / \mathrm{CS}$ as a carrier system for use in agriculture. The results obtained for the encapsulation of $\mathrm{GA}_{3}$ demonstrated the considerable potential of this system for use in the field. Additional studies are in progress in order to obtain a better understanding of the mechanisms of action of these formulations.

\section{Acknowledgements}

The authors are grateful for the financial support provided by the Brazilian agencies São Paulo Science Foundation - FAPESP (projects \#2013/12322-2 and \#2015/15617-9), Brazilian Fellow Agency CNPq (Science without Borders Program, project \#200823/20140 ). We gratefully acknowledge the partial financial support of the Laboratorio Nacional de Materiales Grafénicos, (Mexican agency CONACyT project \#250848).

\section{References}

Abraham, P. M., Barnikol, S., Baumann, T., Kuehn, M., Ivleva, N. P., \& Schaumann, G. E. (2013). Sorption of silver nanoparticles to environmental and model surfaces. Environmental Science E Technology, 47(10), 5083-5091. http://dx.doi. org/10.1021/es303941e

Abruzzo, A., Bigucci, F., Cerchiara, T., Saladini, B., Gallucci, M. C., Cruciani, F., ... \& Luppi, B. (2013). Chitosan/alginate complexes for vaginal delivery of chlorhexidine digluconate. Carbohydrate Polymers, 91(2), 651-658. http://dx. doi.org/10.1016/j.carbpol.2012.08.074

Agresti, C., Tu, Z., Ng, C., Yang, Y., \& Liang, J. F. (2008). Specific interactions between diphenhydramine and $\alpha$-helical poly(glutamic acid) - A new ion-pairing complex for taste masking and $\mathrm{pH}$-controlled diphenhydramine release. European Journal of Pharmaceutics and Biopharmaceutics, 70(1), 226-233. http://dx.doi.org/10.1016/j.ejpb.2008.04.004

Awad, M. A., \& Al-Qurashi, A. D. (2012). Gibberellic acid spray and bunch bagging increase bunch weight and improve fruit quality of Barhee date palm cultivar under hot arid conditions. Scientia Horticulturae, 138, 96-100. http://dx.doi. org/10.1016/j.scienta.2012.02.015

Badawy, M. E. I., \& Rabea, E. I. (2011). A biopolymer chitosan and its derivatives as promising antimicrobial agents against plant pathogens and their applications in crop protection. International Journal of Carbohydrate Chemistry, 2011, e460381. http://dx.doi.org/10.1155/2011/460381

Bajaj, I., \& Singhal, R. (2011). Poly (glutamic acid)-An emerging biopolymer of commercial interest. Bioresource Technology, 102(10), 5551-5561. http://dx. doi.org/10.1016/j.biortech.2011.02.047

Bose, S. K., Yadav, R. K., Mishra, S., Sangwan, R. S., Singh, A. K., Mishra, B., Sangwan, N. S. (2013). Effect of gibberellic acid and calliterpenone on plant growth attributes, trichomes, essential oil biosynthesis and pathway gene expression in differential manner in Mentha arvensis L. Plant Physiology and Biochemistry, 66, 150-158. https://doi.org/10.1016/j.plaphy.2013.02.011

Caddeo, C., Díez-Sales, O., Pons, R., Carbone, C., Ennas, G., Puglisi, G., . . \& Manconi, M. (2016). Cross-linked chitosan/liposome hybrid system for the intestinal delivery of quercetin. Journal of Colloid and Interface Science, 461, 69-78. http:// dx.doi.org/10.1016/j.jcis.2015.09.013

Campos, E. V. R., de Oliveira, J. L., da Silva, C. M. G., Pascoli, M., Pasquoto, T., Lima, R., ... \& Fernandes, L. F. (2015). Polymeric and solid lipid nanoparticles for sustained release of carbendazim and tebuconazole in agricultural applications. Scientific Reports, 5 http://dx.doi.org/10.1038/srep13809

Campos, E. V. R., de Oliveira, J. L., \& Fraceto, L. F. (2014). Applications of controlled release systems for fungicides, herbicides, acaricides, nutrients, and plant growth hormones: A review advanced science. Engineering and Medicine, 6(4), 373-387. http://dx.doi.org/10.1166/asem.2014.1538

Campos, E. V. R., de Oliveira, J. L., Fraceto, L. F., \& Singh, B. (2014). Polysaccharides as safer release systems for agrochemicals. Agronomy for Sustainable Development, 35(1), 47-66. http://dx.doi.org/10.1007/s13593-014-0263-0

Chang, J., Zhong, Z., Xu, H., Yao, Z., \& Chen, R. (2013). Fabrication of poly ( $\gamma$-glutamic acid)-coated $\mathrm{Fe} 3 \mathrm{O} 4$ magnetic nanoparticles and their application in heavy metal removal. Chinese Journal of Chemical Engineering, 21(11), 1244-1250. http://dx.doi.org/10.1016/S1004-9541(13)60629-1

Dar, T. A., Uddin, M., Khan, M. M. A., Ali, A., Hashmi, N., \& Idrees, M. (2015). Cumulative effect of gibberellic acid and phosphorus on crop productivity, biochemical activities and trigonelline production in Trigonella foenum-graecum L. Cogent Food E Agriculture, 1(1), 995950. http://dx.doi.org/ $10.1080 / 23311932.2014 .995950$ 
De Jong, W. H., \& Borm, P. J. (2008). Drug delivery and nanoparticles: Applications and hazards. International Journal of Nanomedicine, 3(2), 133-149.

de Oliveira, J. L., Campos, E. V. R., Gonçalves da Silva, C. M., Pasquoto, T., Lima, R., \& Fraceto, L. F. (2015). Solid lipid nanoparticles Co-loaded with simazine and atrazine: Preparation, characterization, and evaluation of herbicidal activity. Journal of Agricultural and Food Chemistry, 63(2), 422-432. http://dx.doi.org/10. 1021/if5059045

DeRosa, M. C., Monreal, C., Schnitzer, M., Walsh, R., \& Sultan, Y. (2010). Nanotechnology in fertilizers. Nature Nanotechnology, 5(2), 91. http://dx.doi. org/10.1038/nnano.2010.2

E1-Otmani, M., Coggins, C. W., Jr., Agustí, M., \& Lovatt, C. J. (2000). Plant growth regulators in citriculture: World current uses. Critical Reviews in Plant Sciences, 19(5), 395-447. http://dx.doi.org/10.1080/07352689.2000.10131824

Elek, N., Hoffman, R., Raviv, U., Resh, R., Ishaaya, I., \& Magdassi, S. (2010). Novaluron nanoparticles: Formation and potential use in controlling agricultural insect pests. Colloids and Surfaces A: Physicochemical and Engineering Aspects, 372(1-3), 66-72. http://dx.doi.org/10.1016/j.colsurfa.2010.09.034

Emami, J., Boushehri, M. S. S., \& Varshosaz, J. (2014). Preparation, characterization and optimization of glipizide controlled release nanoparticles. Research in Pharmaceutical Sciences, 9(5), 301-314.

Fraceto, L. F., Grillo, R., de Medeiros, G. A., Scognamiglio, V., Rea, G., \& Bartolucci, C. (2016). Nanotechnology in agriculture: Which innovation potential does it have? Frontiers in Environmental Science, 4 http://dx.doi.org/10.3389/fenvs. 2016.00020

Garcia, J. P. D., Hsieh, M.-F., Doma, B. T., Peruelo, D. C., Chen, I.-H., \& Lee, H.-M (2013). Synthesis of gelatin- $\gamma$-Polyglutamic acid-based hydrogel for the in vitro controlled release of epigallocatechin gallate (EGCG) from Camellia sinensis. Polymers, 6(1), 39-58. http://dx.doi.org/10.3390/polym6010039

Georgieva, V., Zvezdova, D., \& Vlaev, L. (2012). Non-isothermal kinetics of thermal degradation of chitosan. Chem Cent J, 6(1), 81-90.

Gref, R., Minamitake, Y., Peracchia, M. T., Trubetskoy, V., Torchilin, V., \& Langer, R. (1994). Biodegradable long-circulating polymeric nanospheres. Science (New York, N.Y.), 263(5153), 1600-1603.

Grillo, R., Abhilash, P. C., \& Fraceto, L. F. (2016). Nanotechnology applied to bio-encapsulation of pesticides. Journal of Nanoscience and Nanotechnology, 16(1), 1231-1234. http://dx.doi.org/10.1166/jnn.2016.12332

Guinesi, L. S., \& Cavalheiro, É. T. G. (2006). The use of DSC curves to determine the acetylation degree of chitin/chitosan samples. Thermochimica Acta, 444(2), 128-133. http://dx.doi.org/10.1016/j.tca.2006.03.003

Hafez, I. H., Berber, M. R., Minagawa, K., Mori, T., \& Tanaka, M. (2010). Design of a multifunctional nanohybrid system of the phytohormone gibberellic acid using an inorganic layered double-hydroxide material. Journal of Agricultural and Food Chemistry, 58(18), 10118-10123. http://dx.doi.org/10.1021/jf102501n

Han, J., Zhou, Z., Yin, R., Yang, D., \& Nie, J. (2010). Alginate-chitosan/hydroxyapatite polyelectrolyte complex porous scaffolds: Preparation and characterization. International Journal of Biological Macromolecules, 46(2), 199-205. http://dx.doi. org/10.1016/j.ijbiomac.2009.11.004

Hans, M. L., \& Lowman, A. M. (2002). Biodegradable nanoparticles for drug delivery and targeting. Current Opinion in Solid State and Materials Science, 6(4), 319-327. http://dx.doi.org/10.1016/S1359-0286(02)00117-1

He, L., Liu, Y., Mustapha, A., \& Lin, M. (2011). Antifungal activity of zinc oxide nanoparticles against Botrytis cinerea and Penicillium expansum. Microbiological Research, 166(3), 207-215. http://dx.doi.org/10.1016/j.micres. 2010.03.003

Hong, D. Y., Lee, J.-S., \& Lee, H. G. (2016). Chitosan/poly-(-glutamic acid nanoparticles improve the solubility of lutein. International Journal of Biological Macromolecules, 85, 9-15. http://dx.doi.org/10.1016/j.ijbiomac.2015.12.044

Ihegwuagu, N. E., Sha'Ato, R., Tor-Anyiin, T. A., Nnamonu, L. A., Buekes, P., Sone, B., \& Maaza, M. (2016). Facile formulation of starch-silver-nanoparticle encapsulated dichlorvos and chlorpyrifos for enhanced insecticide delivery. New Journal of Chemistry, 40(2), 1777-1784. http://dx.doi.org/10.1039/ C5NJ01831E

Jeong, Y.-I., Seo, S.-J., Park, I.-K., Lee, H.-C., Kang, I.-C., Akaike, T., \& Cho, C.-S. (2005). Cellular recognition of paclitaxel-loaded polymeric nanoparticles composed of $\operatorname{poly}(\gamma$-benzyl l-glutamate) and poly(ethylene glycol) diblock copolymer endcapped with galactose moiety. International Journal of Pharmaceutics, 296(1-2), 151-161. http://dx.doi.org/10.1016/j.ijpharm.2005.02.027

Khodakovskaya, M. V., Kim, B.-S., Kim, J. N., Alimohammadi, M., Dervishi, E., Mustafa, T., \& Cernigla, C. E. (2013). Carbon nanotubes as plant growth regulators: Effects on tomato growth, reproductive system, and soil microbial community. Small (Weinheim an Der Bergstrasse, Germany), 9(1), 115-123. http://dx.doi.org/10.1002/smll.201201225

Khot, L. R., Sankaran, S., Maja, J. M., Ehsani, R., \& Schuster, E. W. (2012). Applications of nanomaterials in agricultural production and crop protection: A review. Crop Protection, 35, 64-70. http://dx.doi.org/10.1016/j.cropro.2012.01.007

Kubota, H., Nambu, Y., \& Endo, T. (1995). Convenient esterification of $\operatorname{poly}(\gamma$-glutamic acid $)$ produced by microorganism with alkyl halides and their thermal properties. Journal of Polymer Science Part A: Polymer Chemistry, 33(1), 85-88. https://doi.org/10.1002/pola.1995.080330110.

Kurita, K. (2006). Chitin and chitosan: Functional biopolymers from marine crustaceans. Marine Biotechnology, 8(3), 203-226. http://dx.doi.org/10.1007/ s10126-005-0097-5

Leite, V. M., Rosolem, C. A., \& Rodrigues, J. D. (2003). Gibberellin and cytokinin effects on soybean growth. Scientia Agricola, 60(3), 537-541. http://dx.doi.org/ 10.1590/S0103-90162003000300019
Liao, Z.-X., Peng, S.-F., Chiu, Y.-L., Hsiao, C.-W., Liu, H.-Y., Lim, W.-H., . . . \& Sung, H.-W. (2014). Enhancement of efficiency of chitosan-based complexes for gene transfection with poly $(\gamma$-glutamic acid) by augmenting their cellular uptake and intracellular unpackage. Journal of Controlled Release, 193, 304-315. http:// dx.doi.org/10.1016/j.jconrel.2014.04.024

Liu, Y., Sun, Y., He, S., Zhu, Y., Ao, M., Li, J., \& Cao, Y. (2013). Synthesis and characterization of gibberellin-chitosan conjugate for controlled-release applications. International Journal of Biological Macromolecules, 57, 213-217. http://dx.doi.org/10.1016/j.ijbiomac.2013.03.024

Liu, Y., Sun, Y., Xu, Y., Feng, H., Fu, S., Tang, J., . . . \& Xu, S. (2013). Preparation and evaluation of lysozyme-loaded nanoparticles coated with poly- $\gamma$-glutamic acid and chitosan. International Journal of Biological Macromolecules, 59, 201-207. http://dx.doi.org/10.1016/j.ijbiomac.2013.04.065

Lu, H., Wang, J., Bai, Y., Lang, J. W., Liu, S., Lin, Y., \& Cheng, J. (2011). Ionic polypeptides with unusual helical stability. Nature Communications, 2, 206 http://dx.doi.org/10.1038/ncomms1209

Lynch, J. P., \& Brown, K. M. (2012). New roots for agriculture: Exploiting the root phenome. Philosophical Transactions of the Royal Society of London B: Biological Sciences, 367(1595), 1598-1604. http://dx.doi.org/10.1098/rstb.2011.0243

Manikandan, A., \& Sathiyabama, M. (2016). Preparation of Chitosan nanoparticles and its effect on detached rice leaves infected with Pyricularia grisea. International Journal of Biological Macromolecules, 84, 58-61. http://dx.doi.org/ 10.1016/j.ijbiomac.2015.11.083

Manocha, B., \& Margaritis, A. (2008). Production and characterization of $\gamma$-polyglutamic acid nanoparticles for controlled anticancer drug release. Critical Reviews in Biotechnology, 28(2), 83-99. http://dx.doi.org/10.1080/ 07388550802107483

Martins, A. F., Pereira, A. G. B., Fajardo, A. R., Rubira, A. F., \& Muniz, E. C. (2011). Characterization of polyelectrolytes complexes based on N,N,N-trimethyl chitosan/heparin prepared at different $\mathrm{pH}$ conditions. Carbohydrate Polymers, 86(3), 1266-1272. http://dx.doi.org/10.1016/j.carbpol.2011.06.024

Maruyama, C. R., Guilger, M., Pascoli, M., Bileshy-José, N., Abhilash, P. C., Fraceto, L. F., \& de Lima, R. (2016). Nanoparticles based on chitosan as carriers for the combined herbicides imazapic and imazapyr. Scientific Reports, 6, 19768. http://dx.doi.org/10.1038/srep19768

McDaniel, E., Chen, I., Balogh, E., Yang, Y., \& Ghoshroy, S. (2013). Structural analysis of plants exposed to titanium dioxide (TiO2) nanoparticles. Microscopy and Microanalysis, 19(Suppl. (S2)), 104-105. http://dx.doi.org/10.1017/ S14319276130 02511

Mesejo, C., Reig, C., Martínez-Fuentes, A., \& Agustí, M. (2010). Parthenocarpic fruit production in loquat (Eriobotrya japonica Lindl.) by using gibberellic acid. Scientia Horticulturae, 126(1), 37-41. http://dx.doi.org/10.1016/j.scienta.2010. 06.009

Miransari, M., \& Smith, D. L. (2014). Plant hormones and seed germination. Environmental and Experimental Botany, 99, 110-121. http://dx.doi.org/10. 1016/j.envexpbot.2013.11.005

Mishra, S., Singh, B. R., Singh, A., Keswani, C., Naqvi, A. H., \& Singh, H. B. (2014). Biofabricated silver nanoparticles act as a strong fungicide against Bipolaris sorokiniana causing spot blotch disease in wheat. PUBLIC LIBRARY OF SCIENCE, 9(5), e97881. http://dx.doi.org/10.1371/journal.pone.0097881

Nair, R., Varghese, S. H., Nair, B. G., Maekawa, T., Yoshida, Y., \& Kumar, D. S. (2010). Nanoparticulate material delivery to plants. Plant Science, 179(3), 154-163. http://dx.doi.org/10.1016/j.plantsci.2010.04.012

Nambara, E. (2013). Plant hormones. In S. M. Hughes (Ed.), Brenner's encyclopedia of genetics (2nd ed., pp. 346-348). San Diego: Academic Press. Retrieved from:. http://www.sciencedirect.com/science/article/pii/B9780123749840011700

Ogunleye, A., Bhat, A., Irorere, V. U., Hill, D., Williams, C., \& Radecka, I. (2015). Poly-(-glutamic acid: Production, properties and applications. Microbiology (Reading, England), 161(Pt 1), 1-17. http://dx.doi.org/10.1099/mic.0.081448-0

Oliveira, H. C., Stolf-Moreira, R., Martinez, C. B. R., Grillo, R., de Jesus, M. B., \& Fraceto, L. F. (2015). Nanoencapsulation enhances the post-Emergence herbicidal activity of atrazine against mustard plants. PUBLIC LIBRARY OF SCIENCE, 10(7), e0132971. http://dx.doi.org/10.1371/journal.pone.0132971

Oliveira, H. C., Gomes, B. C. R., Pelegrino, M. T., \& Seabra, A. B. (2016). Nitric oxide-releasing chitosan nanoparticles alleviate the effects of salt stress in maize plants. Nitric Oxide, 61, 10-19. http://dx.doi.org/10.1016/j.niox.2016.09. 010

Palmer, G. H. (1974). The industrial use of gibberellic acid and its scientific basis-A review. Journal of the Institute of Brewing, 80(1), 13-30. http://dx.doi.org/10. 1002/j.2050-0416.1974.tb03578.x

Pavlista, A. D., Santra, D. K., Schild, J. A., \& Hergert, G. W. (2012). Gibberellic acid sensitivity among common bean cultivars (Phaseolus vulgaris L.). HortScience, 47(5), 637-642

Peng, S.-F., Yang, M.-J., Su, C.-J., Chen, H.-L., Lee, P.-W., Wei, M.-C., \& Sung, H.-W. (2009). Effects of incorporation of poly(gamma-glutamic acid) in chitosan/DNA complex nanoparticles on cellular uptake and transfection efficiency. Biomaterials, 30(9), 1797-1808. http://dx.doi.org/10.1016/j.biomaterials.2008. 12.019

Peng, S.-F., Tseng, M. T., Ho, Y.-C., Wei, M.-C., Liao, Z.-X., \& Sung, H.-W. (2011). Mechanisms of cellular uptake and intracellular trafficking with chitosan/DNA/poly( $\gamma$-glutamic acid) complexes as a gene delivery vector. Biomaterials, 32(1), 239-248. http://dx.doi.org/10.1016/j.biomaterials.2010.08. 081

Portilla-Arias, J. A., García-Alvarez, M., Martínez de Ilarduya, A., \& Muñoz-Guerra, S. (2007). Thermal decomposition of microbial poly $(\gamma$-glutamic acid) and 
poly( $\gamma$-glutamate)s. Polymer Degradation and Stability, 92(10), 1916-1924. http://dx.doi.org/10.1016/j.polymdegradstab.2007.06.011

Quiñones, J. P., García, Y. C., Curiel, H., \& Covas, C. P. (2010). Microspheres of chitosan for controlled delivery of brassinosteroids with biological activity as agrochemicals. Carbohydrate Polymers, 80(3), 915-921. http://dx.doi.org/10. 1016/j.carbpol.2010.01.006

Rademacher, W. (2015). Plant growth regulators: Backgrounds and uses in plan production. Journal of Plant Growth Regulation, 34(4), 845-872. http://dx.doi. org/10.1007/s00344-015-9541-6

Rajjou, L., Duval, M., Gallardo, K., Catusse, J., Bally, J., Job, C., \& Job, D. (2012). Seed germination and vigor. Annual Review of Plant Biology, 63(1), 507-533. http:// dx.doi.org/10.1146/annurev-arplant-042811-105550

Riteau, N., \& Sher, A. (2016). Chitosan: An adjuvant with an unanticipated STING. Immunity, 44(3), 522-524. http://dx.doi.org/10.1016/j.immuni.2016.03.002

Rodrigues, C., de Vandenberghe, L. P., de Oliveira, J., \& Soccol, C. R. (2012). New perspectives of gibberellic acid production: A review. Critical Reviews in Biotechnology, 32(3), 263-273. http://dx.doi.org/10.3109/07388551.2011. 615297

Sarmento, B., Ferreira, D., Veiga, F., \& Ribeiro, A. (2006). Characterization of insulin-loaded alginate nanoparticles produced by ionotropic pre-gelation through DSC and FTIR studies. Carbohydrate Polymers, 66(1), 1-7. http://dx.doi. $\operatorname{org} / 10.1016 /$ j.carbpol.2006.02.008

Schaffazick, S. R., Guterres, S. S., de Lucca Freitas, L., \& Pohlmann, A. R. (2003). Physicochemical characterization and stability of the polymeric nanoparticle systems for drug administration. Química Nova, 26(5), 726-737. http://dx.doi. org/10.1590/S0100-40422003000500017

Schwab, F., Zhai, G., Kern, M., Turner, A., Schnoor, J. L., \& Wiesner, M. R. (2015). Barriers, pathways and processes for uptake, translocation and accumulation of nanomaterials in plants-Critical review. Nanotoxicology, 1-22. http://dx.doi. org/10.3109/17435390.2015.1048326

Sekhon, B. S. (2014). Nanotechnology in agri-food production: An overview. Nanotechnology, Science and Applications, 7, 31-53. http://dx.doi.org/10.2147/ NSA.S39406
Servin, A. D., Castillo-Michel, H., Hernandez-Viezcas, J. A., Diaz, B. C., Peralta-Videa, J. R., \& Gardea-Torresdey, J. L. (2012). Synchrotron micro-XRF and micro-XANES confirmation of the uptake and translocation of TiO2 nanoparticles in cucumber (Cucumis sativus) plants. Environmental Science $\mathcal{E}$ Technology, 46(14), 7637-7643. http://dx.doi.org/10.1021/es300955b

Sung, H.-W., Sonaje, K., Liao, Z.-X., Hsu, L.-W., \& Chuang, E.-Y. (2012). pH-responsive nanoparticles shelled with chitosan for oral delivery of insulin: From mechanism to therapeutic applications. Accounts of Chemical Research, 45(4), 619-629. http://dx.doi.org/10.1021/ar200234q

Tao, S., Pang, R., Chen, C., Ren, X., \& Hu, S. (2012). Synthesis, characterization and slow release properties of O-naphthylacetyl chitosan. Carbohydrate Polymers, 88(4), 1189-1194. http://dx.doi.org/10.1016/j.carbpol.2012.01.076

Tewary, V., \& Zhang, Y. (2015). Modeling, characterization and production of nanomaterials: Electronics, photonics and energy applications. Elsevier.

Uto, T., Wang, X., Sato, K., Haraguchi, M., Akagi, T., Akashi, M., \& Baba, M. (2007). Targeting of antigen to dendritic cells with poly $(\gamma$-glutamic acid) nanoparticles induces antigen-specific humoral and cellular immunity. The Journal of Immunology, 178(5), 2979-2986. http://dx.doi.org/10.4049/jimmunol.178.5. 2979

Wani, R. A., Malik, H. T., Malik, A. R., Baba, J. A., \& Dar, N. A. (2014). Studies on apple seed germination and survival of seedlings as affected by Gibberellic Acic under cold arid conditions. Intl J Scientific Technol Res, 3, 210-221.

Zargar, V., Asghari, M., \& Dashti, A. (2015). A review on chitin and chitosan polymers: Structure, chemistry, solubility, derivatives, and applications. ChemBioEng Reviews, 2(3), 204-226. http://dx.doi.org/10.1002/cben. 201400025

Zeng, D., Luo, X., Tu, R., Zeng, D., Luo, X., \& Tu, R. (2012). Application of Bioactive Coatings Based on Chitosan for Soybean Seed Protection, Application of Bioactive Coatings Based on Chitosan for Soybean Seed Protection. International Journal of Carbohydrate Chemistry, 2012(2012), e104565. http:// dx.doi.org/10.1155/2012/104565 